\title{
Senior Pre-service Teachers' Senses of Efficacy on their Technological Pedagogical Content Knowledge (TPACK)
}

\author{
Süleyman Nihat ŞAD* \\ Kübra AÇIKGÜL ${ }^{* *}$ \\ Kenan DELICAN ${ }^{* * *}$
}

Received: 23 July 2013

Accepted: 13 April 2015

\begin{abstract}
This research investigates the preservice teachers' senses of efficacy about their technological pedagogical content knowledge (TPACK) in terms of some variables, and the association between their perceived efficacy and frequency of computer use. It was designed based on a baseline descriptive survey method, followed by associational models of casual-comparison and correlation. The research group comprised 365 senior preservice teachers. The data were collected using TPACK survey developed by Şahin (2011). Results suggested that participants had favorable perceptions of efficacy in terms of TPACK and its domains. While no statistical differences were observed for gender, significant differences were established with regard to department and computer possession variables. Low-to-medium level of positive significant correlations were found between preservice teachers' frequency of computer use and perceived efficacy of TPACK. Finally, Pedagogical Content Knowledge, Technological Pedagogical Knowledge, Technological Content Knowledge, and Pedagogical knowledge were found to be the significant predictors of TPACK.
\end{abstract}

Keywords: preservice teachers, technological pedagogical content knowledge, information and communication technologies

\section{Extended Abstract}

Purpose and Significance: The present research aims to investigate the preservice teachers' senses of efficacy with regard to their technological pedagogical content knowledge (TPACK) in terms of some variables including gender, department, and possession of a computer (desktop/laptop). Moreover, the association between the senior pre-service teachers' perceived efficacy of TPACK and their frequency of computer use was analyzed. Finally, we analyzed the extent to which the specific knowledge domains predict the TPACK in general.

Today the efforts to raise teachers who are able to use technology in effective, attractive and innovative manners have led to the introduction of different approaches of technology integration (Abbitt, 2011). TPACK represents one of the theoretical frameworks commonly referred in training candidate teachers who can integrate technology into effective instruction (Alayyar, Fisser, \& Voogt, 2012; Timur \& Taşar, 2011b). The empirical studies (Angeli \& Valanides, 2009; Chai, Koh, \& Tsai, 2010) also proved that employing the TPACK framework in teacher training process positively contributed to the teachers' capability to integrate technology into teaching process. Thus, it was deemed necessary to investigate to what extent the teacher training

\footnotetext{
* Corresponding Author: Assoc. Prof. Dr., Inonu University, Malatya, Turkey, nihat.sad@inonu.edu.tr

** Research Assistant, Inonu University, Malatya, Turkey, kubra.acikgul@inonu.edu.tr

*** Graduate Student, Inonu University, Malatya, Turkey, kenan.delican@zirve.edu.tr
} 
curricula at universities provide the future teachers with the technological pedagogical content knowledge. From a curriculum evaluation perspective, the data obtained from the present study about the preservice teachers' level of perceived efficacy of TPACK may provide input for future researches on needs analysis in teacher training.

Methods: The research was designed based on a baseline descriptive survey method, followed by associational models of casual-comparison and correlation. The research group comprised 365 senior preservice teachers studying at two medium-scale universities in south-eastern and eastern Anatolian regions of Turkey. The data were collected using the TPACK survey developed by Şahin (2011) for preservice teachers. The 5 -point (" $1=$ not at all,” " $2=$ little,” “ $3=$ moderate,” " $4=$ quite,” and “ $5=$ complete.”) Likert type survey comprises seven subscales including technology knowledge (TK), pedagogy knowledge (PK), content knowledge (CK), technological pedagogical knowledge (TPK), technological content knowledge (TCK), pedagogical content knowledge (PCK), and technological pedagogical content knowledge (TPACK). Subscales include 47 items in total.

The data were analyzed using basic descriptive statistics (arithmetic means and standard deviations), independent samples $t$ test, one way Anova, multiple linear regression analysis, and Pearson correlation coefficients analysis. Based on the Bonferroni correction, the significance level in inferential analyses was considered $\alpha=0,01(0,05 / 5)$ (Abdi, 2010). Also, the practical significance was tested using effect size formula including Cohen $\mathrm{d}$ for $t$ test, Cohen $f$ for Anova, $R^{2}$ for Regression analysis and Pearson correlation test.

Results: The participants' scores from seven knowledge domains of TPACK survey ranged between $\bar{x}=3.73$ and $\bar{x}=3.56$ which falls into the interval of quite according to Likert scaling. TK-Technology Knowledge stands to be the domain with relatively the lowest mean score $(\bar{x}=3.56)$. These results indicated that participating senior preservice teachers had favorable perceptions of efficacy in terms of TPACK in general and in each of the specific domain. While no statistical difference was observed in terms of gender, significant differences were established with regard to variables of department and computer possession. Accordingly, senior preservice Computer and Technology teachers were found to have significantly higher levels of perceived efficacy in terms of all TPACK domains except for CK-Content Knowledge than seniors from other teaching departments. Similarly, senior preservice English Language teachers' perceived efficacy scores in most TPACK domains except for TPK-Technological Pedagogical Knowledge and TCK-Technological Content Knowledge domains were found significantly higher than seniors in most other programs. On the other hand, senior preservice Elementary Mathematics and Social Studies teachers were found to perceive themselves significantly less efficient in most of the TPACK domains. As for the possession of computers (desktop/laptop), senior preservice teachers who possess a computer were found to have significantly higher perceived efficacy in TPACK 
domains except for PCK-Pedagogical Content Knowledge. Low-to-medium level of positive significant correlations (ranging between $r=0.144$ and $r=0.571$ ) were found between pre-service teachers' frequency of computer use and perceived efficacy of TPACK. Finally, the results of regression analysis indicated sub domains of TPACK altogether had a positive and high level of correlation with general TPACK scores $(\mathrm{R}=$ 0.779, $\left.\mathrm{R}^{2}=0.606 ; \mathrm{F}_{(6,358)}=91.921, \mathrm{p}=0.000\right)$. Specifically, PCK-Pedagogical Content Knowledge $(\beta=0.296)$, TPK-Technological Pedagogical Knowledge $(\beta=0.272)$, TCKTechnological Content Knowledge $(\beta=0.246)$, and PK-Pedagogical Knowledge ( $\beta=0.164)$ were found to be the significant predictors of TPACK.

Discussion and Conclusions: As a result of the study it was concluded that participating senior preservice teachers had favorable perceptions of efficacy in terms of general and specific knowledge domains regarding TPACK. This result is promising in terms of teacher training since first of all teachers should have self-confidence in order to use technology in their lessons (Akgün, 2013). No matter if their knowledge of technology is fine, it is not enough if teachers are not also confident of using that knowledge in order to facilitate student learning (Ertmer \& Ottenbreit-Leftwich, 2010). Yan and Piper (2003) for example found that self-efficacy is a significant variable among elementary and secondary teachers in terms of technology use in their classes.

On the other hand, considering that TK-Technology Knowledge had relatively the lowest score, possessing a computer makes a significant difference in preservice teachers' perceived efficacy in TK-Technology Knowledge, and there was a medium level of positive correlation between frequency of computer use and perceived efficacy in $T K$ Technology Knowledge, it can be inferred that in order to increase their senses of efficacy in TK-Technology Knowledge preservice teachers should be provided with computers and made more frequent users of computers and other ICT. And preferably their use of ICT should be directed to more pedagogical purposes. 


\section{Eğitim Fakültesi Son Sınıf Öğrencilerinin Teknolojik Pedagojik Alan Bilgilerine (TPAB) İlişkin Yeterlilik Algiları}

\author{
Süleyman Nihat ŞAD ${ }^{*} \quad$ Kübra AÇIKGÜL ${ }^{* *}$
}

\author{
Kenan DELICAN ${ }^{* * *}$
}

ÖZET: Bu araştırmada eğitim fakültesi son sınıf öğrencilerinin teknolojik pedagojik alan bilgilerine (TPAB) ilişkin yeterlilik algılarının bazı değişkenler açısından incelenmesi ve TPAB yeterlilik algısı ile bilgisayar kullanma sıklığı değişkenleri arasındaki ilişkinin incelenmesi amaçlanmıştır. Araştırma betimsel tarama modeline ve nedenselkarşılaştırma ile korelasyonel yöntemlerin kullanıldığı ilişkisel tarama modeline göre tasarlanmıştır. Çalışmaya eğitim fakültesi son sınıfına devam eden 365 öğrenci katılmıştır. Veriler Şahin (2011) tarafından geliştirilen TPAB ölçme aracı kullanılarak toplanmıştır. Araştırmanın sonucunda, öğlecilerin genel TPAB ve alt bilgi alanlarına ilişkin yeterliliklerini iyi düzeyde algıladıkları belirlenmiştir. TPAB yeterlilik düzeylerinin cinsiyet değişkenine göre istatistiksel olarak anlamlı düzeyde farklılaşmadığı gözlenirken, bölüm ve bilgisayar sahibi olma durumu değişkenlerine göre anlamlı düzeyde farklılaştığı bulunmuştur. Öğrencilerin bilgisayar kullanma sıklıkları ile TPAB yeterlilik düzeyleri arasında düşük ve orta düzeyde pozitif yönde anlamlı ilişkiler bulunmuştur. Son olarak, Öğrencilerin TPAB yeterlilik algılarının en güçlü yordayıcılarının Pedagojik Alan Bilgisi, Teknolojik Pedagoji Bilgisi, Teknolojik Alan Bilgisi ve Pedagoji Bilgisi yeterlilik algıları olduğu görülmüştür.

Anahtar sözcükler: öğretmen adayları, teknolojik pedagojik alan bilgisi, bilgi ve iletişim teknolojileri

\section{Giriş}

Teknolojik yenilikler, eğitim sisteminin yapısını ve öğretim ortamlarında uygulanan öğrenme-öğretme faaliyetlerini etkilemektedir (Kuş, 2005). Etkili bir öğretim için teknolojinin etkili ve yaratıcı bir şekilde kullanılması gerekir (Ertmer ve OttenbreitLeftwich, 2010; Şad, 2008). Birçok eğitimci, öğretmen ve araştırmacı için teknoloji, eğitimde yüksek kalitenin göstergesi haline gelmiştir (Çakır ve Yıldırım, 2009). Ancak teknolojinin etkin kullanımı, gerekli donanımın montajı ve yazılımların yüklenmesinden ibaret değildir (Armstrong ve diğ., 2005). Öğretmenlerden, teknolojiyi derslerinin amaçlarına hizmet edecek şekilde, doğru pedagojiyle harmanlayarak kullanması beklenir (Armstrong ve diğ. 2005; Demir, Özmantar, Bingölbali ve Bozkurt, 2011; Ertmer ve Ottenbreit-Leftwich, 2010; Kreijns, Vermeulen, Kirschner, van Buuren ve van Acker 2013; Şad ve Özhan, 2012; Şad ve Göktaş, 2014). Bu bağlamda öğretmenler teknolojiyi kullanırken öğrencilerinin gereksinimlerine uygun araç ve yöntemler seçmeli, öğretim yöntemlerini etkili bir biçimde tasarlamalı ve yeni öğretim stratejilerini geliştirebilmelidir (Demiraslan ve Koçak Usluel, 2008). Kısacası öğretmenler, teknolojiyi genelde öğretim programına, özelde ders planlarına etkili bir şekilde entegre edebilmelidir (Albion, 1999). Ancak öğretmenin teknolojiyi öğretim sürecine başarılı bir şekilde entegre edebilmesi, hem pedagoji bilgisine, hem alan bilgisine hem de teknoloji bilgisine yeteri düzeyde sahip olmasını gerektirir (Jang ve Tsai, 2012). Dolayısıyla öğretmenlik mesleğinin gerektirdiği alan bilgisi ve pedagoji bilgisinin

\footnotetext{
* Sorumlu Yazar: Doç. Dr., İnönü Üniversitesi, Malatya, nihat.sad@inonu.edu.tr

** Araştırma Görevlisi, İnönü Üniversitesi, Malatya, kubra.acikgul@inonu.edu.tr

*** Yüksek Lisans Öğrencisi, İnönü Üniversitesi, Malatya, kenan.delican@zirve.edu.tr
} 
yanında, öğretmenlerin teknolojinin etkili kullanımına yönelik bilgi ve becerilere sahip olmaları da gerekmektedir (Çakır ve Yıldırım, 2009).

Öğretmenlik mesleğinin gerektirdiği yeterliliklerin kapsamının, alan ve pedagoji bilgisinin yanında teknoloji bilgi ve becerisini de içerecek şekilde genişlemesinin bir sonucu olarak, günümüzde Teknolojik Pedagojik Alan Bilgisi (TPAB) kavramı ortaya çıkmıştır (Jang ve Tsai, 2012; Mishra ve Koehler, 2006; Timur ve Taşar, 2011a). TPAB yapılanmasının temelinde alan (içerik) bilgisi, pedagoji bilgisi ve teknoloji bilgisi olmak üzere üç temel bilgi alanı ve bunların kesişimlerinden oluşan yeterlilik alanları mevcuttur (Koehler ve Mishra, 2005b). Günümüzde etkin ve verimli şekilde teknolojiyi kullanma yeteneğine sahip öğretmenleri hazırlama işi yükseköğretim kurumları bünyesinde yürütülen öğretmen yetiştirme programlarının sorumluluğu haline gelmiştir (Abbitt ve Klett, 2007). TPAB ise teknoloji bilgi ve becerisine sahip öğretmen adaylarının yetiştirilmesi sürecinde öğretmen yeterlilikleri açısından yaygın olarak başvurulan kavramsal bir çerçeve haline gelmiştir (Alayyar ve diğ., 2012; Timur ve Taşar, 2011b). Bu doğrultuda öğretmenlik mesleğinin gerektirdiği teknolojik pedagojik alan bilgisinin eğitim fakülteleri tarafından öğretmen adaylarına ne düzeyde kazandırıldığının belirlenmesi araştırmaya değer görülmektedir. Program değerlendirme kapsamında öğretmen adaylarının teknoloji entegrasyonu konusundaki hazırbulunuşluk düzeylerinine ilişkin elde edilecek veriler öğretmen yetiştirme programlarının geliştirilmesi amacıyla yürütülecek ihtiyaç analizi çalışmalarına girdi sunabilir.

\section{Teknolojik Pedagojik Alan Bilgisi (TPAB)}

Kuramsal anlamda TPAB çerçevesi Shulman'ın (1986) tanımladığı alan bilgisi ve pedagojik bilgi alanlarının kesişimlerinden oluşan pedagojik alan bilgisi (PAB) üzerine inşa edilmiştir (Jang ve Tsai, 2012; Mishra ve Koehler, 2006). Shulman (1986) pedagojik alan bilgisini, öğretmenin dersinin konusunu öğrencilerine anlaşılır bir şekilde sunmak ve açıklamak için başvurduğu en etkili yolları (analojiler, çizimler, örnekler, açıklamalar vb.) kapsayan bir çerçeve olarak tanımlamıştır.

Şekil 1. TPAB Çerçevesi

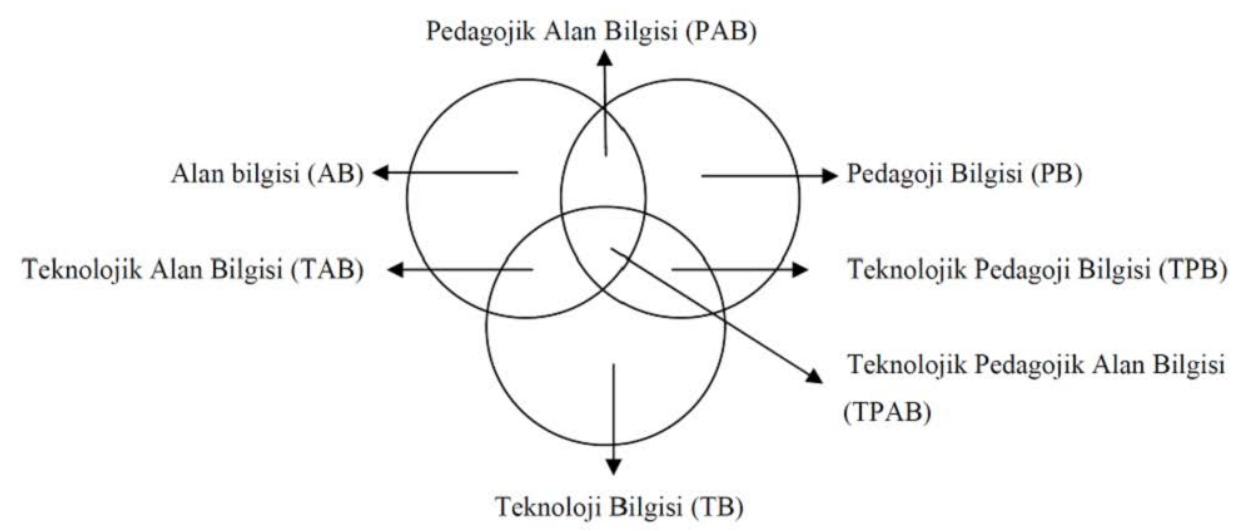

Uyarlandı̆̆l yayın: Mishra ve Koehler (2006, s. 1025) 
Mishra ve Koehler (2006) alan bilgisi ve pedagoji bilgisine, teknoloji bilgisini de ekleyerek üç yeni bilgi alanı oluşturmuşlardır. Bunlar; teknolojik pedagojik alan bilgisi (TPAB), teknolojik alan bilgisi (TAB) ve teknolojik pedagojik bilgi (TPB) alanlarıdır (bkz. şekil 1). Bu yeni yapılanmayla birlikte teknoloji, pedagoji ve içerik bilgisi ve bunların kesişiminden oluşan toplam yedi bilgi alanı ortaya çıkmıştır: Alan Bilgisi, Pedagoji Bilgisi, Teknoloji Bilgisi, Pedagojik Alan Bilgisi, Teknolojik Alan Bilgisi, Teknolojik Pedagoji Bilgisi ve Teknolojik Pedagojik Alan Bilgisi (Harris, Mishra ve Koehler, 2009; Koehler ve Mishra, 2005a, 2005b, 2008; Mishra ve Koehler, 2006, 2008). Aşağıda bu bilgi alanlarına ilişkin öz açıklamalar sunulmuştur:

Alan Bilgisi (AB): Her dersin öğrenilecek veya öğretilecek konularıyla ilgili sahip olunan bilgi.

Pedagoji Bilgisi (PB): Öğrenme ve öğretme süreçleri ve uygulamalarına ilişkin derinlikli bilgi.

Teknoloji Bilgisi (TB): Bireyin, sürekli güncellenen teknolojileri iş ya da özel hayatından üretken bir şekilde kullanabilmesi için gerekli bilgi.

Pedagojik Alan Bilgisi (PAB): Özelde belirli bir konu alanının (Matematik, Fen vb.) öğrenme ve öğretme süreçlerine ilişkin pedagoji bilgisi.

Teknolojik Pedagoji Bilgisi (TPB): Çeşitli teknolojilerin öğrenme ve öğretme süreçlerinde nasıl kullanılabileceğine ve ne tür katkılar sağlayabileceğine dair bilgi.

Teknolojik Alan Bilgisi (TAB): Teknoloji ve konu alanının karş1lıklı olarak birbirlerinden nasıl etkilendiklerine ve birbirlerini gerektirdiklerine dair bilgi (T1pta kullanılan x-ray cihazları ya da fizik ve matematikte kullanılan dijital simülasyon yazılımları bu etkileşime örnek verilebilir).

Teknolojik Pedagojik Alan Bilgisi (TPAB): Kendisini oluşturan bilgi alanlarının toplamından daha fazlasi olan TPAB teknoloji, pedagoji ve alan bilgisinin etkileşiminden oluşan yeni bir yapıdır. İlgili konu alanının hedeflerinin, gerekli öğretim teknolojilerini işe koşmak suretiyle öğrencilerin bireysel öğrenme ihtiyaçlarına uygun olarak etkili bir şekilde nasıl kazandırılması gerektiğine dair bilgidir.

Harris, Mishra ve Koehler (2009, s. 401), TPAB'1 “teknolojik ve pedagojik açıdan mahir ve dersin öğretim programının gerekleri doğrultusunda öğretim yapan öğretmenlerin kullandıkları mesleki bir bilgi türü” olarak tanımlamıştır. Öğretmenlerin sahip olduğu teknolojik pedagojik alan bilgisi, eğitim teknolojilerini nasıl algıladıklarının ve teknolojiyi kullanarak etkili bir öğretim sağlamak için teknoloji, pedagoji ve alan bilgilerini nasıl harmanladıklarının bir göstergesidir (Timur ve Taşar, 2011b).

Öğretmenlerin ya da öğretmen adaylarının Teknolojik Pedagojik Alan Bilgilerinin belirlenmesi konusunda farklı yaklaşımlar mevcuttur. Bu farklılaşmalara neden olan temel sorunun TPAB çerçevesinin bilgi (knowledge) kavramıyla sınırlanmasından kaynaklandığı söylenebilir. Tek başına alan, pedagoji ve teknoloji bilgilerinden bahsedilebilse de öğretmenlerden beklenen bu üç alanı birleştirerek etkili bir öğretim yapabilmeleridir. Öyleyse bunun nasıl yapılabileceğine ilişkin bilgiden 
ziyade, hem bilgi hem de beceriden bahsedilmelidir. Uygulamada bu bilgi ya da beceriyi ölçebilmenin zorluğu, araştırmacıları öğretmen ya da öğretmen adaylarına kendi TPAB düzeylerini nasıl algıladıklarına dair dolaylı sorular sormaya sevk etmektedir. Örneğin Archambault ve Barnett (2010) araştırma sınırlılığ olarak doğrudan gözlemlenen davranışları ölçemedikleri için katılımcıların kendi bilgi düzeylerini nasıl algıladıklarını (Zayıf-Mükemmel arası) sorduklarını belirtmişlerdir. Graham ve arkadaşları (2009) katılımcıların TPAB düzeylerini, kendilerine duydukları güven başlığı altında, Schmidt ve arkadaşları (2009) ise özdeğerlendirme başlığı altında ölçmüştür. Angeli ve Valanides (2009), TPAB’1 ölçerken sadece öz-değerlendirme değil akran ve uzman değerlendirmesinin de kullanılmasını önermiştir. Diğer taraftan TPAB'i, özyeterlilik algısı çerçevesine inceleyen yaklaşımlar da mevcuttur (Abbitt ve Klett, 2007; Gömleksiz ve Fidan, 2011; Kaya, Özdemir, Emre ve Kaya, 2011). Bandura (1997) tarafından geliştirilen Sosyal Öğrenme Kuramı'nın önemli bir unsuru olan özyeterlilik algısı, "bireyin gelecekte karşılaşabileceği durumlarla başa çıkabilmek için gerekli eylemleri planlayıp hayata geçirebilme kapasitesine dair duyduğu inanç" (s. 2) olarak tanımlanabilir. Bu bağlamda Abbitt (2011) özyeterlilik algısının, öğretmenlerin teknolojiyi öğretime başarılı bir şekilde entegre edebilme yeteneklerine olan inançlarının gelecekteki öğretim uygulamalarına etkisini anlamak adına önemli bir temel sunduğunu savunur.

Öğretmen adaylarının ve öğretmenlerin özyeterlilik inançları, eğitim araştırmacılarının önemli çalışma konularından birisi olmuştur (Akkuş, 2013; Baki, Kutluca ve Birgin, 2008; Bıkmaz, 2004; Erdem, 2007). Öğretmenlerin, mesleki yeterlilikleri yerine getirmeleri onların iyi eğitim almalarının yanı sıra, bu yeterlilikleri yerine getirebileceklerine olan inançları ile de yakından ilgilidir (Yılmaz, Köseoğlu, Gerçek ve Soran, 2004). Özyeterlilik algısı bir kişi tarafından sahip olunan gerçek yeterlilik düzeyinden çok kişinin yeterlilik düzeyi hakkındaki inancıyla ilgilidir (Albion, 2000; Kurbanoğlu, 2004). Buna rağmen konunun eğitimciler tarafından ilgi çekici olmasının nedeni özyeterlilik algısının, bireyin davranışların anlamlı bir yordayıcısı olmasıdır (Al awaidi ve Alghazo, 2012). Öğretmenlerin sahip oldukları özyeterlilik inançları, öğretimle ilgili belirledikleri hedefleri, öğretime harcadığı çabayı ve isteklilik düzeylerini etkilemektedir (Tschannen-Moran ve Hoy, 2001). Bireyin yeterlilik algis1 bir işe ne kadar çaba harcayacağını, işi ne kadar sürdüreceğini ve zorluklar karşısında ne kadar çabuk pes edeceğini önemli ölçüde yordar (Erdem, 2007). Kısacası, bireylerin arzuladıkları bir sonuca ulaşabilme yeterliliğine dair inançları onların duygularını, düşüncelerini, güdülerini ve eylemlerini olumlu ya da olumsuz yönde etkilemektedir (Abbitt, 2011; Bandura, 1997). Dolayısıyla öğretmenlerin genel olarak öğretimle ilgili davranışlarını (Yenilmez ve Kakmacı, 2008) özelde de teknolojiyi derslerine entegre etmeye yönelik davranışlarını (Abbitt, 2011; Abbitt ve Klett 2007; Al awaidi ve Alghazo, 2012; Albion 1999, 2000; Enochs, Riggs, ve Ellis, 1993; Ertmer, Conklin ve Lewandowski, 2003; Wang, Ertmer ve Newby, 2004) yordamada özyeterlilik inançlarından yararlanılabilir. Örneğin, Albion (1999), öğretmenlerin teknolojiyi etkili bir şekilde kullanabilme kapasitelerine olan inançlarının (özyeterlilik algılarının), derslerde bilgisayar kullanımlarını etkileyen önemli bir faktör olduğunu bulmuştur. 
Yine Kutluca ve Ekici (2010) bilgisayar-destekli eğitim etkinliklerinin başarıyla uygulanabilmesi için öğretmen adaylarının bilgisayar destekli eğitime dair olumlu tutuma ve özyeterlilik inancına sahip olması gerektiğini vurgulamaktadır.

$\mathrm{Bu}$ açıklamalar doğrultusunda mevcut çalışmada öğretmen adaylarının TPAB yeterlilik algı düzeylerinin belirlenmesi ve bazı değişkenler açısından incelenmesi önemli görülmüştür. Albion (2000), öğretmen adaylarının sadece alg1 düzeylerinin belirlenmesinin yeterli olmadığını belirterek algı düzeylerine etki eden değişkenlerinde incelenmesi gerektiğini ileri sürmüştür. Yapılan çalışmalar incelediğinde dikkat çeken değişkenlerden birisinin cinsiyet olduğu görülmektedir. Birçok araştırmacı TPAB düzeyi üzerinde cinsiyetin etkisini araştırmış ve farklı sonuçlar elde etmiştir. Bazı araştırmacılar cinsiyetin TPAB düzeyi üzerinde anlamlı bir fark yaratmadığı sonucuna ulaşmıştır (Akgün, 2013; Gömleksiz ve Fidan, 2011; Kaya, Emre ve Kaya, 2010; Kaya ve diğ., 2011; Kazu ve Erten, 2011; Koh ve Sing, 2011; Mutluoğlu ve Erdoğan, 2012; Sancar-Tokmak vd., 2013). Diğer taraftan, Erdoğan ve Şahin'in (2010) matematik öğretmen adaylarıyla yürüttükleri çalışma sonuçları erkek öğretmen adaylarının TPAB düzeylerinin kadınlarınkinden anlamlı düzeyde yüksek olduğunu göstermiştir. Tsai (2008) yaptığı çalışma da erkek öğretmenlerin bayan öğretmenlere göre bilgisayar kullanımı konusunda kendilerine daha çok güvendiklerini ortaya koyarken, çalışmalarında TB boyutunda erkek ve kadın öğretmen adayları arasında erkekler lehine anlamlı bir farklılık olduğunu belirlemişlerdir. Geçmiş araştırmalarda ayrıca bilgisayar sahibi olma durumunun TPAB düzeyinin farklılaşması üzerinde etkisi olup olmadığı incelenmiş ve bu konuda da cinsiyete benzer şekilde farklı sonuçlara ulaşılmıştır (Mutluoğlu ve Erdoğan, 2012; Yavuz Konokman, Yanpar Yelken ve Sancar Tokmak, 2013). Öğretmen adaylarının öğrenim gördükleri bölümlerin de TPAB düzeyleri üzerinde etkisi olduğu düşünülmektedir. Nitekim yapılan çalışmalar bu görüşü destekleyen sonuçlar vermektedir (Gömleksiz ve Fidan; Kaya ve diğ., 2011). Yapılan çalışmalarda yer alan diğer bir değişken bilgisayar kullanım sıklığıdır. İlgili alanyazında bilgisayar kullanımım sıklığının artmasının teknoloji kullanımına ilişkin algı üzerinde olumlu etkiler yarattığına dair araştırma bulguları mevcuttur (Baki ve diğ., 2008; Demiralay ve Karadeniz, 2010; Yurdakul Kabakçı, 2011; Yavuz Konokman ve diğ., 2013). Bu açıklamalar 1şı̆̆ında yapılan çalışmalarda elde edilen sonuçlar cinsiyet, bölüm/program, bilgisayar sahibi olma ve bilgisayar kullanma sıklığı değişkenlerinin öğretmen adaylarının TPAB düzeyi açısından önemli olabileceğini göstermektedir.

\section{Öğretmen Yetiştirme Bağlamında TPAB}

Günümüzde öğretmen adaylarının teknoloji okuryazarı olmaları beklenmektedir (Martinovic ve Zhang, 2012). Teknoloji okuryazarlığı kapsamı geniş bir kavram olmakla birlikte, pedagojik bir bakış açısıyla, bir öğretmenin teknoloji okuryazarlığından söz ederken, teknolojiyi dersinin amaçlarına hizmet edecek şekilde, doğru pedagojiyle harmanlayarak kullanabilmesi kastedilmelidir. $\mathrm{Bu}$, teknolojinin eğitime/öğretime entegre edilmesi olarak da tanımlanabilir. Ancak mevcut araştırmalar, öğretmenlerin teknoloji entegrasyonu konusunda yeterli olmadığına, özelde öğrenci öğrenmelerini güdüleyen ve artıran eğitim teknolojilerini eğitim-öğretim ortamlarında 
yeteri kadar kullanmadıklarını dair bulgular sunmaktadır (İşman, 2002). Örneğin Yılmaz (2007), yaptı̆̆ı literatür taramasında sınıf öğretmenlerinin derste teknoloji kullanımı konusunda yetersiz oldukları ve bu yetersizliğin genellikle araç-gereç yokluğundan ve teknolojiyi bozma endişesinden kaynaklandığını bildirmiştir. Bozkurt ve Cilavdaroğlu, (2011) matematik ve sınıf öğretmenlerinin, internetten bilgi ve materyal paylaşımına sıcak bakmadıklarını, birçok öğretmenin cebir ve geometri yazılımlarını hemen hemen hiç kullanmadığını bulmuştur. Archambault ve Crippen (2009) öğretmenlerin pedagoji bilgilerini, alan bilgilerini ve pedagojik alan bilgilerini iyi algilamakla birlikte teknoloji bilgisi konusunda kendilerini daha az yeterli algıladıklarını bulmuştur. Yeni teknolojilerin sunduğu potansiyelin yeterince kullanılmaması ve geleneksel araç-gereçlerle yapılanların tekrarlanması (örneğin etkileşimli elektronik tahtanın yalnızca metin yansıtmak amacıyla kullanılması) öğretmenlerin teknoloji konusundaki yetersizliklerinin bir başka göstergesidir (Demir ve diğ. 2011; Şad ve Özhan, 2012).

Günümüzde başta yeni nesil öğretmenler olmak üzere öğretmenlerin bilişim ve iletişim teknolojilerinin öğretime etkili bir şekilde entegrasyonu konusunda gerekli bilgi, tutum ve beceriler kazanmaları beklenmektedir. Ancak Martinovic ve Zhang'a (2012) göre ilgili teknolojilerin pedagojik bir şekilde nasıl kullanılması gerektiğine dair yeterli rol modelin sunulmaması ve bu teknolojilere erişimin sınırlı olması nedeniyle teknolojinin öğretime entegrasyonu konusunda sorunlar devam etmektedir. Gürbüztürk, Duruhan ve Şad (2009) benzer şekilde öğretmen adaylarının, kendilerini yetiştiren öğretim elemanlarını pedagojik açıdan yetersiz bulduklarını saptamışlardır. Peralta ve Costa (2007) öğretmenlerin bilgi ve iletişim teknolojilerini, öğrenme ilkelerini yeterince işe koşamadan kullandıklarına dikkat çekmiştir. Liu (2012) araştırmaya katılan Tayvanlı öğretmenlerin çoğunun öğrenci merkezli öğretmenlik inançlarına sahip olmalarına rağmen yapılandırmacı öğretimle teknolojiyi entegre edemediklerini aktarmıştır. Demir ve Bozkurt (2011) ilköğretim matematik öğretmenlerin katıldığı çalışmada öğretmenlerin teknoloji ve pedagoji alanlarında mesleki gelişim eğitimine ihtiyaç duyduklarını bulmuştur. $\mathrm{Bu}$ da teknoloji entegrasyonunun alan bilgisi ve pedagojiden bağımsız olamayacağının önemli bir kanıtıdır. Angeli ve Valanides (2009) alan bilgisi, teknoloji ve pedagojinin tek başına bilinmesinin yeterli olmadığını, bunların nasıl harmanlanması gerektiğinin mutlaka öğretilmesi gerektiğini özellikle vurgulamıştır.

Öğretmenleri derslerinde teknolojiyi etkin ve verimli şekilde kullanabilecek düzeyde eğitmek yükseköğretim kurumlarında öğretmen yetiştirme programlarının sorumluluğu haline gelmiştir (Abbitt ve Klett, 2007). Teknolojinin, öğretmen yetiştirme programlarına entegre edilmesi ise kapsamlı bir program geliştirme sürecini gerektirmektedir. Zira, teknolojiyi pedagojiyle kaynaştırabilme becerisini tek bir teknoloji dersiyle kazandırmaya çalışmak yerine, disiplinlerarası bir programlama yaklaşımıyla teknoloji entegrasyonunun tüm derslerde modellenmesi ve öğretilmesi gerekmektedir (Sutton, 2011). Aldunate ve Nussbaum (2013) öğretmen adaylarının yeni ve karmaşık öğretim teknolojilerine kolayca uyum sağlayarak derslerinde 
kullanabilmeleri için bu konuda o kadar fazla yaşantı geçirmeleri gerektiğini vurgulamaktadir.

Derslerinde teknolojiyi etkili, ilgi çekici ve yenilikçi bir şekilde kullanabilecek öğretmenler yetiştirme çabası, teknoloji entegrasyonuyla ilgili çeşitli yaklaşımların kullanılmasına neden olmuştur (Abbitt, 2011). Günümüzde teknolojiyi öğretim sürecinde kullanabilen öğretmen adaylarının yetiştirilmesi sürecinde yaygın olarak başvurulan kavramsal çerçevelerden biri TPAB'dir (Alayyar ve diğ. 2012; Timur ve Taşar, 2011b). Yapılan empirik çalışmalar (Angeli ve Valanides, 2009; Chai, Koh, ve Tsai, 2010) bu çerçevenin öğretmen yetiştirme sürecine dahil edilmesinin öğretmen adaylarının teknolojiyi öğretim sürecine entegre etme konusunda uzmanlaşmalarına olumlu katkı sağladığını göstermektedir.

\section{Amaç}

$\mathrm{Bu}$ araştırmanın temel amacı, eğitim fakültelerinin farklı bölümlerinin son sınıflarında öğrenim gören öğrencilerin teknolojik pedagojik alan bilgilerine (TPAB) ilişkin yeterlilik algılarını belirlemektir. Ayrıca öğrencilerin TPAB yeterlilik algılarının cinsiyet, bölüm/program ve bilgisayar sahibi olma değişkenleri açısından incelemesi amaçlanmaktadır. Üçüncü olarak TPAB yeterlilik algısı ile bilgisayar (masaüstü/dizüstü) kullanma sıklığı değişkeni arasındaki ilişkiyi tespit etmek amaçlanmıştır. Son olarak da öğrencilerin TPAB alt alanlarına ilişkin yeterlilik algılarının genel TPAB’a ait yeterlilik algılarını ne düzeyde yordadığı incelenmiştir.

\section{Yöntem}

\section{Araştırmanın Deseni}

$\mathrm{Bu}$ araştırmada temelde eğitim fakültesi son sınıf öğrencilerinin TPAB'a yönelik yeterlilik algılarının belirlenmesi amaçlandığından nicel araştırma desenlerinden betimsel tarama (survey) modeli kullanılmıştır. Araştırmada bu betimsel yaklaşımın ötesinde öğrencilerin TPAB yeterlilik algılarının cinsiyet, bölüm ve bilgisayar sahibi olma durumlarına göre karşılaştırılması da amaçlandığından ilişkisel tarama modellerinden nedensel-karşılaştırma yaklaşımı da kullanılmıştır. Ayrıca TPAB alt boyutlarının genel TPAB algısını yordama durumu ve algılanan TPAB yeterlilik düzeyi ile bilgisayar kullanma sıklığı arasındaki ilişkinin incelenmesi ise ilişkisel tarama modellerinden korelasyonel yaklaşıma uygun olarak yapılmıştır. İlişkisel modeller, iki veya daha fazla değişken arasındaki ilişkilerin varlığını ve ilişkinin derecesini incelemek, neden-sonuç ile ilgili ipuçları elde etmek ve incelenen olguları daha iyi anlayabilmek amacıyla kullanılır (Büyüköztürk, Çakmak, Akgün, Karadeniz ve Demirel, 2010; Karasar, 2012).

\section{Çalışma grubu}

Araştırmanın çalışma grubunu, Güneydoğu Anadolu Bölgesi ve Doğu Anadolu Bölgesinde bulunan orta büyüklükte iki üniversitenin Eğitim Fakültelerinin farklı bölümlerinin normal öğretim programlarında öğrenim gören öğrenciler oluşturmuştur. 
Öğretmen adaylarının TPAB yeterlilik algılarına ilişkin daha geçerli veriler elde edebilmek için çalışmaya katılacak öğrencilerin belirlenmesinde TPAB kuramsal çerçevesinin kapsadığı bilgi türlerine yönelik dersleri almış olmaları önemli görülmüştür. Bu nedenle, söz konusu derslerin tamamına yakınını almış olan son sınıf öğrencileri araştırmaya dâhil edilmiştir. Çalışmaya katılan bölümlerin isimleri ve öğrenci sayıları Tablo 1'de sunulmuştur. Güneydoğu Anadolu Bölgesinde bulunan üniversitede öğrenim gören toplam son sınıf öğrenci sayısı 196 olmasına rağmen bu öğrencilerden 113'üne, Doğu Anadolu Bölgesi'nde bulunan üniversitede öğrenim gören toplam son sınıf öğrenci sayısı 506 olmasına rağmen bu öğrencilerin de 252'sine ulaş1larak veri toplanabilmiştir. Buna göre Güneydoğu Anadolu Bölgesi'nde yer alan üniversitenin çalışma evreninin yaklaşık \%58'ine, Doğu Anadolu Bölgesi'nde bulunan üniversitenin ise çalışma evreninin yaklaşık \%50'sine ulaşılmıştır. Veriler 2011-2012 akademik yılı bahar yarıyılında toplanmıştır.

Tablo 1

Araştırmaya Katılan Öğrencilerin Okullara ve Bölümlere Göre Dă̆ılımı

\begin{tabular}{|c|c|c|c|}
\hline $\begin{array}{c}\text { Üniversitenin } \\
\text { bulunduğu bölge }\end{array}$ & Program/bölüm & $\begin{array}{l}\text { Öğrenci } \\
\text { Sayıları }\end{array}$ & $\%$ \\
\hline & Türkçe Öğretmenliği & 42 & 11.51 \\
\hline Güneydoğu Anadolu & İlköğretim Matematik öğretmenliği & 36 & 9.86 \\
\hline \multirow[t]{6}{*}{ Bölgesi } & Sınıf Öğretmenliği & 35 & 9.59 \\
\hline & Toplam & 113 & 30.96 \\
\hline & Türkçe Öğretmenliği & 32 & 8.77 \\
\hline & Sınıf Öğretmenliği & 22 & 6.03 \\
\hline & İngilizce Öğretmenliği & 20 & 5.48 \\
\hline & PDR Öğretmenliği & 20 & 5.48 \\
\hline \multirow{7}{*}{ Doğu Anadolu Bölgesi } & ВÖTE & 23 & 6.30 \\
\hline & Müzik Öğretmenliği & 27 & 7.40 \\
\hline & Okul Öncesi Öğretmenliği & 37 & 10.14 \\
\hline & Sosyal Bilgiler Öğretmenliği & 44 & 12.05 \\
\hline & Beden Eğitimi Öğretmenliği & 27 & 7.40 \\
\hline & Toplam & 252 & 69.04 \\
\hline & Genel Toplam & 365 & 100 \\
\hline
\end{tabular}

\section{Veri Toplama Aracı}

$\mathrm{Bu}$ çalışmada öğrencilerin TPAB ile ilgili yeterlilik algılarını belirlemek amacıyla Şahin (2011) tarafından geliştirilen Öğretmen Adaylarının Teknolojik 
Pedagojik Alan Bilgisi (TPAB) adlı ölçme aracı kullanılmıştır. Ölçme aracında kişisel bilgilerle ilgili 5, TPAB-Teknolojik Pedagojik Alan Bilgisi (5 madde; örn. Ders içeriğini, uygun teknoloji ve öğretim ilke/yöntemleri ile bütünleştirme...) ve alt bilgi alanlarına [TB-Teknoloji bilgisi (15 madde; örn. Bilgisayarda çıkan teknik bir sorunu giderme...), PB-Pedagojik bilgi (6 madde; örn. Öğrenci performansını değerlendirme...), AB-Alan bilgisi (6 madde; örn. Alanımdaki temel konuları...), TPBTeknolojik pedagojik bilgi (4 madde; örn. Yeni bir teknolojinin eğitim-öğretime uygunluğunu değerlendirme...), TAB-Teknolojik alan bilgisi (4 madde; örn. Alanıma özgü teknolojileri (bilgisayar uygulamalarını)...) ve PAB-pedagojik alan bilgisi (7 madde; örn. Sınıf/okul içi etkinlikleri içeren bir ders planını rahatlıkla hazırlayabilme...)] yönelik toplam 47 madde vardır. 5'li Likert yapı kullanılan ölçekte yanıt kategorileri (1) Hiç bilmiyorum, (2) Az düzeyde biliyorum, (3) Orta düzeyde biliyorum, (4) İyi düzeyde biliyorum, (5) Çok iyi düzeyde biliyorum şeklindedir. Katılımcıların ölçek maddelerine verdikleri cevaplar kendileriyle ilgili gerçek durumu değil, bu konuda kendilerini ne kadar yeterli hissettiklerine dair algılarını yansıtmaktadır. Bu açıdan ölçülen özelliğin gerçek bilgi ya da beceri düzeyi değil, algılanan yeterlilik düzeyi olduğu varsayılmıştır.

Alt ölçeklerin geçerlik ve güvenirlik çalışmaları Şahin (2011) tarafından 348 öğretmen adayından elde edilen veriler kullanılarak yapılmıştır. TPAB ve alt bilgi alanlarına ilişkin bağımsız faktör analizleri sonuçlarına göre alt ölçeklerde yer alan maddelerin faktör yükleri 0,599 ile 0,903 arasında bulunmuştur. Alt ölçeklerin açıkladığı toplam varyans oranları TB-Teknoloji bilgisi için \%51.87; PB-Pedagojik bilgi için \%69.09; AB-Alan bilgisi için \%59.3; TPB-Teknolojik Pedagojik bilgi için \%74.48; TAB-Teknolojik alan bilgisi için \%74.77; PAB-pedagojik alan bilgisi için \%69.02 ve TPAB-Teknolojik Pedagojik Alan Bilgisi için \%76.1'dir. Alt ölçeklerin güvenirliğine ilişkin analiz sonuçlarına göre madde toplam korelasyon katsayıları 0.618 ile 0.899 arasında değerler almıştır. Ölçeklerin kararlılık açısından güvenilirliğine ilişkin test-tekrar test analizleri sonucunda $r=0.77$ ile $r=0.86$ arasında değişen pozitif yönde, anlamlı ve yüksek düzeyde ilişkiler saptanmıştır. Alt ölçeklerin Cronbach Alpha iç tutarlılık katsayıları ise TB-Teknoloji Bilgisi için $\alpha=0.93$, PB için $\alpha=0.90$, AB için $\alpha=0.86$, TPB için $\alpha=0.88$, TAB için $\alpha=0.88$, PAB için $\alpha=0.92$ ve TPAB için $\alpha=0.92$ olarak hesaplanmıştır. Bu çalışmada 365 son sınıf öğrencisinden elde edilen veri seti üzerinden yapılan güvenirlik analizi sonucunda Cronbach Alpha iç tutarlılık katsayıları TB için $\alpha=0.94$, PB için $\alpha=0.81$, AB için $\alpha=0.79$, TPB için $\alpha=0.80$, TAB için $\alpha=0.77$, PAB için $\alpha=0.82$ ve TPAB için $\alpha=0.76$ olarak hesaplanmıştır.

\section{Verilerin Analizi}

Verilerin analizinde öncelikle TPAB bilgi alanlarına ait yedi alt ölçekten alınan puanların aritmetik ortalamaları ve standart sapmaları hesaplanmıştır. Cinsiyetlerine ve bilgisayara sahip olma durumuna göre öğrencilerin TPAB yeterlilik algı düzeyleri arasında anlamlı bir fark olup olmadığını belirlemek amacıyla bağımsız gruplar için ttesti; bölüm değişkenine göre anlamlı bir fark olup olmadığını belirlemek için ise tek yönlü Anova testi kullanılmıştır. Bilgisayar kullanma sıklığı değişkeni ile öğrencilerin 
algıladıkları TPAB yeterlilik düzeyleri arasında anlamlı bir ilişki olup olmadığını belirlemek için Pearson korelasyon analizi yapılmıştır. TPAB alt alanlarına ait puanların genel TPAB yeterlilik algısı puanlarını yordama düzeyi çoklu doğrusal regresyon analizi kullanılarak test edilmiştir. Yapılan Bonferroni düzeltmesi sonucu araştırmada toplam beş analiz kullanıldığı için çıkarımsal analizlerde anlamlılık düzeyi $\alpha=0.01$ (0.05/5) olarak belirlenmiştir (Abdi, 2010). Ayrıca elde edilen sonuçların pratikteki anlamlılığını ortaya koymak amacıyla etki büyüklükleri hesaplanmıştır. Yapılan t testi sonuçları için Cohen d, Anova testi için Cohen f, Regresyon analizi ve Pearson korelasyon testi için $\mathrm{R}^{2}$ değerleri hesaplanmıştır. Elde edilen etki büyüklükleri Cohen $\mathrm{d}$ için; 0.20 “ küçük”, 0.50 “orta”, 0.80 "büyük” etki büyüklüğü; Cohen f için 0.10 “küçük”, 0.25 “orta”, 0.40” büyük” etki büyüklüğü olarak yorumlanmıştır (Cohen, 1988). $\mathrm{R}^{2}$ için ise <0.1 “zayıf”, 0.11-0.3 “küçük”, 0.31-0.5 “orta” ve >0.5 “büyük” etki büyüklüğü olarak yorumlanmıştır (Muijs, 2004, s. 166)

Araştırmaya katılan son sınıf öğrencilerinin TPAB ve alt bilgi alanlarına ilişkin yeterlilik puanlarının karşılaştırmalı olarak yorumlanabilmesi amacıyla her ölçeğin toplam puanları madde sayılarına bölünerek 5'li derecelendirme puanlarına dönüştürülmüştür. Bu puan ortalamalarının yorumlanmasında aşağıdaki puan aralıkları ve karşılık gelen yeterlilik düzeyleri kullanılmıştır.

Tablo 2

Algılanan TPAB yeterlilik puanların yorumlanması amacıyla kullanılan puan aralıkları

\begin{tabular}{ll}
\hline Puan aralığı & Algılanan Yeterlilik Düzeyi \\
\hline $1.00-1.80$ & Hiç bilmiyorum \\
$1.81-2.60$ & Az düzeyde biliyorum \\
$2.61-3.40$ & Orta düzeyde biliyorum \\
$3.41-4.20$ & İyi düzeyde biliyorum \\
$4.21-5.00$ & Çok iyi düzeyde biliyorum \\
\hline
\end{tabular}




\section{Bulgular}

\section{Öğrencilerin TPAB Yeterlilik Algıları}

Eğitim fakültelerinin farklı bölümlerinin son sınıflarında eğitim gören öğrencilerin teknolojik pedagojik alan bilgisi yeterlilik düzeylerine yönelik bulgular Tablo 3'te verilmiştir.

Tablo 3

Ö̆̆rencilerin algıladıkları TPAB yeterlilik düzeylerinin dă̆ılımı $(n=365)$

\begin{tabular}{|c|c|c|c|}
\hline Alt ölçek & $\overline{\mathrm{x}}$ & ss & Algılanan Yeterlilik düzeyi \\
\hline PAB & 3.7393 & .61357 & İyi düzeyde biliyorum \\
\hline ТРАВ & 3.7211 & .62063 & İyi düzeyde biliyorum \\
\hline РB & 3.6913 & .62483 & İyi düzeyde biliyorum \\
\hline ТPB & 3.6788 & .69762 & İyi düzeyde biliyorum \\
\hline $\mathrm{AB}$ & 3.6114 & .66488 & İyi düzeyde biliyorum \\
\hline TAB & 3.6082 & .69826 & İyi düzeyde biliyorum \\
\hline ТВ & 3.5649 & .84247 & İyi düzeyde biliyorum \\
\hline
\end{tabular}

Yapılan betimsel analiz sonuçlarına göre öğrencilerin algıladıkları TPAB yeterlilik düzeyleri ortalama 3.56 ile 3.73 arasında değişmektedir. Bütün alt ölçeklerden alınan puanların ortalaması "Iyi düzeyde biliyorum" aralığına karşılık gelmektedir. Ortalamalar incelendiğinde pedagoji bilgisini içeren alt ölçeklerin (PAB, TPAB, PB ve TPB) puan ortalamalarının diğerlerinden nispeten daha yüksek olduğu görülmektedir. $\mathrm{Bu}$ bulgudan hareketle öğrencilerin başta pedagojik bilgiyi içeren alanlar olmak üzere bütün alanlarda kendilerini iyi düzeyde yeterli algıladıkları söylenebilir. 


\section{Cinsiyet Değişkenine Göre Öğrencilerin TPAB Yeterlilik Algıları}

Öğrencilerin algıladıkları teknolojik pedagojik alan bilgisi yeterlilik düzeylerinin cinsiyet değişkenine göre anlamlı düzeyde farklılaşıp farklılaşmadığına ilişkin bulgular Tablo 4'te verilmiştir.

Tablo 4

Ö̆rrencilerin Algıladıkları TPAB puanlarının cinsiyetine göre t-testi analizi sonuçları

\begin{tabular}{|c|c|c|c|c|c|c|c|}
\hline Boyutlar & Cinsiyet & $N$ & $\overline{\mathrm{x}}$ & ss & $S d$ & $t$ & $p$ \\
\hline \multirow{2}{*}{ TB } & Kadın & 186 & 3.53 & 0.85 & \multirow{2}{*}{363} & \multirow{2}{*}{0.846} & \multirow{2}{*}{.398} \\
\hline & Erkek & 179 & 3.60 & 0.83 & & & \\
\hline \multirow{2}{*}{ PB } & Kadın & 186 & 3.71 & 0.65 & \multirow{2}{*}{363} & \multirow{2}{*}{0.432} & \multirow{2}{*}{.666} \\
\hline & Erkek & 179 & 3.68 & 0.60 & & & \\
\hline \multirow{2}{*}{$\mathrm{AB}$} & Kadın & 186 & 3.64 & 0.65 & \multirow{2}{*}{363} & \multirow{2}{*}{0.752} & \multirow{2}{*}{.453} \\
\hline & Erkek & 179 & 3.58 & 0.68 & & & \\
\hline \multirow{2}{*}{ ТРВ } & Kadın & 186 & 3.72 & 0.69 & \multirow{2}{*}{363} & \multirow{2}{*}{1.201} & \multirow{2}{*}{.230} \\
\hline & Erkek & 179 & 3.63 & 0.70 & & & \\
\hline \multirow{2}{*}{ TAB } & Kadın & 186 & 3.61 & 0.71 & \multirow{2}{*}{363} & \multirow{2}{*}{0.130} & \multirow{2}{*}{.896} \\
\hline & Erkek & 179 & 3.60 & 0.68 & & & \\
\hline \multirow{2}{*}{ PAB } & Kadın & 186 & 3.78 & 0.60 & \multirow{2}{*}{363} & \multirow{2}{*}{1.401} & \multirow{2}{*}{.162} \\
\hline & Erkek & 179 & 3.69 & 0.63 & & & \\
\hline \multirow{2}{*}{ ТРАВ } & Kadın & 186 & 3.73 & 0.61 & \multirow{2}{*}{363} & \multirow{2}{*}{0.417} & \multirow{2}{*}{.677} \\
\hline & Erkek & 179 & 3.71 & 0.63 & & & \\
\hline
\end{tabular}

${ }^{*} \mathrm{p}<0.01$ (Bonferroni düzeltmesi sonrası)

Tablo 4'teki veriler incelendiğinde, öğrencilerin TPAB ve alt bilgi alanlarından aldıkları puanların cinsiyet değişkenine göre istatistiksel olarak anlamlı düzeyde farklılaşmadığı görülmektedir. Ortalamalar incelendiğinde kadın ve erkek öğrencilerin TPAB ve alt bilgi alanlarına ilişkin yeterlilik algılarının “iyi düzeyde biliyorum” puan aralığına karşılık geldiği ve benzer düzeyde olduğu söylenebilir. 


\section{Bölüm Değişkenine Göre Öğrencilerin TPAB Yeterlilik Algıları}

Öğrencilerin algıladıkları teknolojik pedagojik alan bilgisi yeterlilik düzeylerinin bölüm değişkenine göre betimsel istatistikleri Tablo 5'te ve puanlar arasında anlamlı düzeyde farklılaşma olup olmadığına ilişkin ANOVA sonuçları Tablo 6'de verilmiştir.

Tablo 5

Öğrencilerin TPAB puanlarının bölüm değişkenine göre betimsel analiz sonuçları

\begin{tabular}{|c|c|c|c|c|c|c|c|c|c|c|c|c|c|c|c|}
\hline \multirow[b]{2}{*}{ Bölüm } & \multirow[b]{2}{*}{$N$} & \multicolumn{2}{|c|}{ TB } & \multicolumn{2}{|c|}{ PB } & \multicolumn{2}{|c|}{$\mathrm{AB}$} & \multicolumn{2}{|c|}{ ТРВ } & \multicolumn{2}{|c|}{ TAB } & \multicolumn{2}{|c|}{ PAB } & \multicolumn{2}{|c|}{ ТРАВ } \\
\hline & & $\bar{X}$ & SS & $\bar{X}$ & SS & $\bar{X}$ & SS & $\bar{X}$ & SS & $\overline{\mathrm{X}}$ & SS & $\bar{X}$ & SS & $\bar{X}$ & SS \\
\hline 1. İlk. Mat. & 36 & 3.24 & 0.55 & 3.37 & 0.60 & 3.39 & 0.73 & 3.35 & 0.72 & 3.36 & 0.75 & 3.50 & 0.78 & 3.32 & 0.71 \\
\hline 2. Sinıf & 57 & 3.54 & 0.82 & 3.81 & 0.61 & 3.41 & 0.62 & 3.68 & 0.76 & 3.66 & 0.80 & 3.74 & 0.64 & 3.68 & 0.75 \\
\hline 3. İng & 20 & 3.81 & 0.59 & 3.97 & 0.40 & 4.17 & 0.49 & 3.90 & 0.45 & 3.66 & 0.64 & 4.02 & 0.29 & 3.65 & 0.51 \\
\hline 4. PDR & 20 & 3.43 & 0.84 & 3.78 & 0.63 & 3.69 & 0.57 & 3.79 & 0.64 & 3.71 & 0.58 & 3.68 & 0.52 & 3.90 & 0.47 \\
\hline 5. ВÖTE & 23 & 4.98 & 0.04 & 3.87 & 0.26 & 3.94 & 0.60 & 4.16 & 0.66 & 4.09 & 0.44 & 4.14 & 0.39 & 4.21 & 0.39 \\
\hline 6. Bed. Ĕ̆t. & 27 & 3.54 & 0.55 & 3.60 & 0.58 & 3.72 & 0.69 & 3.43 & 0.57 & 3.44 & 0.67 & 3.47 & 0.51 & 3.68 & 0.48 \\
\hline 7. Müzik & 27 & 3.66 & 0.81 & 3.90 & 0.47 & 3.89 & 0.50 & 3.82 & 0.49 & 3.77 & 0.67 & 3.97 & 0.45 & 3.88 & 0.49 \\
\hline 8. Türkçe & 74 & 3.45 & 0.83 & 3.64 & 0.67 & 3.60 & 0.64 & 3.69 & 0.68 & 3.62 & 0.69 & 3.77 & 0.56 & 3.78 & 0.60 \\
\hline $\begin{array}{l}\text { 9. Okul. } \\
\text { Önc. }\end{array}$ & 37 & 3.70 & 0.65 & 3.91 & 0.65 & 3.66 & 0.66 & 3.83 & 0.66 & 3.65 & 0.59 & 3.80 & 0.57 & 3.85 & 0.54 \\
\hline 10. Sos. Bil. & 44 & 3.10 & 0.92 & 3.37 & 0.68 & 3.34 & 0.68 & 3.46 & 0.78 & 3.38 & 0.70 & 3.55 & 0.74 & 3.52 & 0.57 \\
\hline Total & 365 & 3.56 & 0.84 & 3.69 & 0.62 & 3.61 & 0.66 & 3.68 & 0.70 & 3.61 & 0.70 & 3.74 & 0.61 & 3.72 & 0.62 \\
\hline
\end{tabular}


Tablo 6

Öğrencilerin TPAB puanlarının bölüm değişkenine göre ANOVA analizi sonuçları

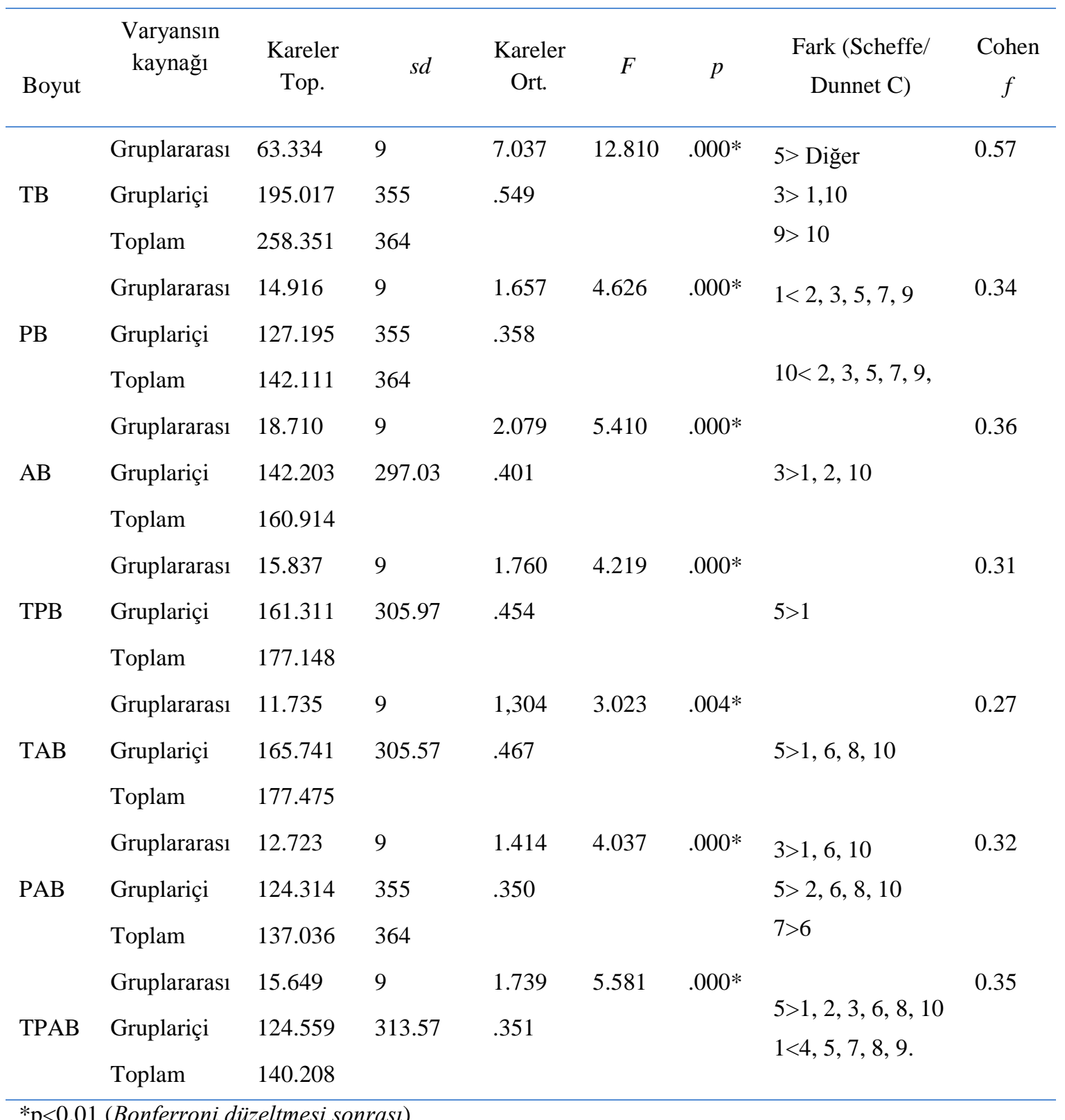

Tablo 6'daki veriler incelendiğinde, öğrencilerin algıladıkları TB yeterlilik puanlarının bölümlerine göre istatistiksel olarak anlamlı düzeyde farklılaştığı görülmektedir $\left[\mathrm{F}_{(9 ; 35)}=12.810, \mathrm{p}<.01\right]$. Bu fark için hesaplanan etki büyüklügünün (Cohen $\mathrm{f}=0.57$ ) geniş olduğu gözlemlenmiştir. Farkın hangi gruplardan kaynaklandığını bulmak amacıyla yapılan Scheffe testi sonucunda, BÖTE son sınıf öğrencilerinin algıladıkları TB yeterlilik puanlarının ( $\overline{\mathrm{x}}=4.98$; çok iyi düzeyde biliyorum) diğer tüm bölüm öğrencilerinin puanlarından; İngilizce öğretmenliği son sınıf öğrencilerinin algıladıkları TB yeterlilik puanlarının ( $\overline{\mathrm{x}}=3.81$; iyi düzeyde biliyorum), İlköğretim Matematik ( $\overline{\mathrm{x}}=3.24$; orta düzeyde biliyorum) ve Sosyal Bilgiler $(\overline{\mathrm{x}}=3.10$; orta düzeyde 
biliyorum) öğrencilerinin puanlarından; ve Okul Öncesi öğretmenliği öğrencilerinin TB puanlarının ( $\overline{\mathrm{x}}=3.70$; iyi düzeyde biliyorum) da Sosyal Bilgiler öğretmenliği öğrencilerinin TB puanlarından $(\overline{\mathrm{x}}=3.10$; orta düzeyde biliyorum) anlamlı düzeyde daha yüksek olduğu bulunmuştur.

Öğrencilerin algıladıkları PB yeterlilik puanları, bölümlerine göre istatistiksel olarak anlamlı düzeyde farklılaşmaktadır $\left[\mathrm{F}_{(9 ; 35)}=4.626, \mathrm{p}<.01\right] . \mathrm{Bu}$ fark için hesaplanan etki büyüklüğünün (Cohen $\mathrm{f}=0.34$ ) orta olduğu gözlemlenmiştir. Farkın hangi gruplardan kaynaklandığını bulmak amacıyla yapılan Scheffe testi sonucunda, Sınıf öğretmenliği ( $\overline{\mathrm{x}}=3.81$; iyi düzeyde biliyorum $)$, İngilizce öğretmenliği $(\overline{\mathrm{x}}=3.97$; iyi düzeyde biliyorum), Müzik öğretmenliği ( $\overline{\mathrm{x}}=3.90$; iyi düzeyde biliyorum), BÖTE ( $\overline{\mathrm{x}}=3.87$; iyi düzeyde biliyorum) ve Okul öncesi öğretmenliği ( $\bar{X}=3.91$; iyi düzeyde biliyorum) bölümü öğrencilerinin puanlarının İlköğretim Matematik ( $\overline{\mathrm{x}}=3.37$; orta düzeyde biliyorum) ve Sosyal Bilgiler ( $\overline{\mathrm{x}}=3.37$; orta düzeyde biliyorum) öğretmenliği son sınıf öğrencilerinin algıladıkları PB yeterlilik puanlarından anlamlı düzeyde daha yüksek olduğu bulunmuştur.

Öğrencilerin algıladıkları AB yeterlilik puanları, bölümlerine göre istatistiksel olarak anlamlı düzeyde farklılaşmaktadır $\left[\mathrm{F}_{(9 ; 297.033)}=5.410, \mathrm{p}<.01\right] . \mathrm{Bu}$ fark için hesaplanan etki büyüklüğünün (Cohen $\mathrm{f}=0.36)$ orta olduğu gözlemlenmiştir. Farkın hangi gruplardan kaynaklandığını bulmak amacıyla yapılan Scheffe testi sonucunda, İngilizce öğretmenliği bölümü son sınıf öğrencilerinin algıladıkları AB yeterlilik puanlarının ( $\overline{\mathrm{x}}=4.17$; iyi düzeyde biliyorum) Sosyal Bilgiler $(\overline{\mathrm{x}}=3.34$; orta düzeyde biliyorum), İlköğretim Matematik ( $\bar{x}=3.39$; iyi düzeyde biliyorum) ve Sinıf $(\bar{x}=3.41$; iyi düzeyde biliyorum) öğretmenliği bölümü son sınıf öğrencilerinin puanlarından anlamlı düzeyde daha yüksek olduğu bulunmuştur.

Öğrencilerin TPB yeterlilik puanları, bölümlerine göre istatistiksel olarak anlamlı düzeyde farklılaşmaktadır $\left[\mathrm{F}_{(9 ; 305.976)}=4.219, \mathrm{p}<.01\right]$. Bu fark için hesaplanan etki büyüklüğünün (Cohen $\mathrm{f}=0.31$ ) orta olduğu gözlemlenmiştir. Farkın hangi gruplardan kaynaklandığını bulmak amacıyla yapılan Scheffe testi sonucunda, BÖTE öğrencilerinin TPB yeterlilik puanlarının ( $\overline{\mathrm{x}}=4.16$; iyi düzeyde biliyorum), İlköğretim Matematik ( $\overline{\mathrm{x}}=3.35$; orta düzeyde biliyorum) öğrencilerinin puanlarından anlamlı düzeyde daha yüksek olduğu bulunmuştur.

Öğrencilerin algılanan TAB yeterlilik puanları, bölümlerine göre istatistiksel olarak anlamlı düzeyde farklılaşmaktadır $\left[\mathrm{F}_{(9 ; 305.570)}=3.023, \mathrm{p}<.01\right] . \mathrm{Bu}$ fark için hesaplanan etki büyüklüğünün (Cohen $\mathrm{f}=0.27$ ) orta olduğu gözlemlenmiştir. Farkın hangi gruplardan kaynaklandığını bulmak amacıyla yapılan Scheffe testi sonucunda, BÖTE öğrencilerinin algıladıkları TAB yeterlilik puanlarının $(\overline{\mathrm{x}}=4.09$; iyi düzeyde biliyorum); İlköğretim Matematik ( $\overline{\mathrm{x}}=3.36$; orta düzeyde biliyorum), Sosyal Bilgiler öğretmenliği ( $\overline{\mathrm{x}}=3.38$; orta düzeyde biliyorum), Türkçe öğretmenliği $(\overline{\mathrm{x}}=3.62$; iyi düzeyde biliyorum) ve Beden Eğitimi öğretmenliği ( $\overline{\mathrm{x}}=3.44$; iyi düzeyde biliyorum) öğrencilerinin puanlarından anlamlı düzeyde daha yüksek olduğu bulunmuştur.

Öğrencilerin algılanan PAB yeterlilik puanları, bölümlerine göre istatistiksel olarak anlamlı düzeyde farklılaşmaktadır $\left[\mathrm{F}_{(9 ; 355)}=4.037, \mathrm{p}<.01\right] . \mathrm{Bu}$ fark için 
hesaplanan etki büyüklüğünün (Cohen $\mathrm{f}=0.32$ ) orta olduğu gözlemlenmiştir. Farkın hangi gruplardan kaynaklandığını bulmak amacıyla yapılan Scheffe testi sonucunda, İngilizce Öğretmenliği ( $\overline{\mathrm{x}}=4.02$; iyi düzeyde biliyorum $)$ bölüm öğrencilerinin puanlarının İlköğretim Matematik Öğretmenliği ( $\bar{x}=3.50$; iyi düzeyde biliyorum), Sosyal Bilgiler Öğretmenliği ( $\overline{\mathrm{x}}=3.55$; iyi düzeyde biliyorum) ve Beden Eğitimi Öğretmenliği ( $\overline{\mathrm{x}}=3.47$; iyi düzeyde biliyorum) son sınıf öğrencilerinin algıladıkları PAB yeterlilik puanlarından; BÖTE $(\overline{\mathrm{x}}=4.14$; iyi düzeyde biliyorum $)$ bölümü öğrencilerinin puanlarının Sosyal Bilgiler ( $\overline{\mathrm{x}}=3.55$; iyi düzeyde biliyorum), Beden Eğitimi ( $\overline{\mathrm{x}}=3.47$; iyi düzeyde biliyorum), Sınıf $(\overline{\mathrm{x}}=3.74$; iyi düzeyde biliyorum) ve Türkçe ( $\bar{x}=3.77$; iyi düzeyde biliyorum) öğretmenliği son sınıf öğrencilerinkinden; Müzik öğretmenliği ( $\overline{\mathrm{x}}=3.97$; iyi düzeyde biliyorum) bölüm öğrencilerinin puanlarının da Beden Eğitimi öğretmenliği son sınıf öğrencilerinin algıladıkları PAB yeterlilik puanlarından ( $\overline{\mathrm{x}}=3.47$; iyi düzeyde biliyorum) anlamlı düzeyde daha yüksek olduğu bulunmuştur.

Öğrencilerin algıladıkları TPAB yeterlilik puanları, bölümlerine göre istatistiksel olarak anlamlı düzeyde farklılaşmaktadır $\left[\mathrm{F}_{(9 ; 313.569)}=5.581, \mathrm{p}<.01\right] . \mathrm{Bu}$ fark için hesaplanan etki büyüklügünün (Cohen $\mathrm{f}=0.35$ ) orta olduğu gözlemlenmiştir. Farkın hangi gruplardan kaynaklandığını bulmak amacıyla yapılan Scheffe testi sonucunda, BÖTE ( $\overline{\mathrm{x}}=4.21$; çok iyi düzeyde biliyorum) öğrencilerinin puanlarının, İngilizce ( $\overline{\mathrm{x}}=3.65$; iyi düzeyde biliyorum), İlköğretim Matematik ( $\overline{\mathrm{x}}=3.32$; orta düzeyde biliyorum), Sosyal Bilgiler ( $\overline{\mathrm{x}}=3.52$; iyi düzeyde biliyorum), Beden Eğitimi ( $\overline{\mathrm{x}}=3.68$; iyi düzeyde biliyorum), Sınıf ( $\overline{\mathrm{x}}=3.68$; iyi düzeyde biliyorum) ve Türkçe $(\bar{x}=3.78$; iyi düzeyde biliyorum) öğretmenliği son sınıf öğrencilerinin algıladıkları TPAB yeterlilik puanlarından anlamlı düzeyde daha yüksek olduğu bulunmuştur. Ayrıca İlköğretim Matematik Öğretmenliği $(\bar{x}=3.32$; orta düzeyde biliyorum) son sınıf öğrencilerinin algıladıkları TPAB yeterlilik algılarının, BÖTE $(\overline{\mathrm{x}}=4.21$; çok iyi düzeyde biliyorum), Türkçe ( $\overline{\mathrm{x}}=3.78$; iyi düzeyde biliyorum), Müzik ( $\overline{\mathrm{x}}=3.88$; iyi düzeyde biliyorum), Okul Öncesi ( $\overline{\mathrm{x}}=3.85$; iyi düzeyde biliyorum) ve $\operatorname{PDR}(\overline{\mathrm{x}}=3.90$; iyi düzeyde biliyorum) bölüm öğrencilerinin puanlarından anlamlı düzeyde daha düşük bulunmuştur.

\section{Bilgisayar (Masaüstü/dizüstü) Sahibi Olma Durumuna Göre Öğrencilerin TPAB Yeterlilik Algıları}

Öğrencilerin algıladıkları teknolojik pedagojik alan bilgisi yeterlilik düzeylerinin Bilgisayar (Masaüstü/dizüstü) sahibi olma durumu değişkenine göre anlamlı düzeyde farklılaşıp farklılaşmadığına ilişkin bulgular Tablo 7'de verilmiştir. 
Tablo 7

Öğrencilerin TPAB puanlarının bilgisayar sahibi olma durumuna göre t-testi analizi

\begin{tabular}{|c|c|c|c|c|c|c|c|c|}
\hline Boyutlar & $\begin{array}{c}\text { Bilgisayar } \\
\text { (Masaüstü/dizüstü) }\end{array}$ & $N$ & $\overline{\mathrm{x}}$ & ss & $s d$ & $t$ & $p$ & Cohen $d$ \\
\hline \multirow{2}{*}{ ТВ } & Yok & 77 & 3.07 & 0.84 & \multirow{2}{*}{362} & \multirow{2}{*}{6.078} & \multirow{2}{*}{$.000^{*}$} & \multirow{2}{*}{0.79} \\
\hline & Var & 287 & 3.70 & 0.79 & & & & \\
\hline \multirow{2}{*}{ PB } & Yok & 77 & 3.52 & 0.67 & \multirow{2}{*}{362} & \multirow{2}{*}{2.684} & \multirow{2}{*}{$.008^{*}$} & \multirow{2}{*}{0.35} \\
\hline & Var & 287 & 3.74 & 0.61 & & & & \\
\hline \multirow{2}{*}{$\mathrm{AB}$} & Yok & 77 & 3.41 & 0.69 & \multirow{2}{*}{362} & \multirow{2}{*}{3.008} & \multirow{2}{*}{$.003^{*}$} & \multirow{2}{*}{0.40} \\
\hline & Var & 287 & 3.67 & 0.65 & & & & \\
\hline \multirow{2}{*}{ ТPB } & Yok & 77 & 3.52 & 0.79 & \multirow{2}{*}{107.203} & \multirow{2}{*}{2.009} & \multirow[t]{2}{*}{.047} & \\
\hline & Var & 287 & 3.72 & 0.67 & & & & \\
\hline \multirow{2}{*}{ TAB } & Yok & 77 & 3.42 & 0.78 & \multirow{2}{*}{107.732} & \multirow{2}{*}{2.413} & \multirow{2}{*}{.018} & \\
\hline & Var & 287 & 3.66 & 0.67 & & & & \\
\hline \multirow{2}{*}{ PAB } & Yok & 77 & 3.70 & 0.67 & \multirow{2}{*}{362} & \multirow{2}{*}{0.653} & \multirow{2}{*}{.514} & \\
\hline & Var & 287 & 3.75 & 0.60 & & & & \\
\hline \multirow{2}{*}{ ТРАВ } & Yok & 77 & 3.59 & 0.63 & \multirow{2}{*}{362} & \multirow{2}{*}{2.139} & \multirow{2}{*}{.033} & \\
\hline & Var & 287 & 3.76 & 0.61 & & & & \\
\hline
\end{tabular}

${ }^{*} \mathrm{p}<0.01$ (Bonferroni düzeltmesi sonrasl)

Tablo 7'deki veriler incelendiğinde, öğrencilerin $\mathrm{TB}\left[t_{(362)}=6.078, \mathrm{p}<.01\right]$; $\mathrm{PB}$ $\left[t_{(362)}=2.684, \mathrm{p}<.01\right] ; \mathrm{AB}\left[t_{(362)}=3.008, \mathrm{p}<.01\right)$ boyutları için algıladıkları yeterlilik düzeylerinin bilgisayar sahibi olanlarının lehine istatistiksel olarak anlamlı düzeyde farklılaştığı görülmektedir. Hesaplanan Cohen $d$ etki büyüklüğü değerleri incelendiğinde, bilgisayar sahibi olma durumunun öğrencilerin algıladıkları yeterlilik düzeyleri üzerinde TB alanı için büyüğe yakın (Cohen $\mathrm{d}=$.79); PB (Cohen $\mathrm{d}=.35$ ) ve $\mathrm{AB}$ (Cohen $\mathrm{f}=.40$ ) boyutlarında ise küçük etkiye sahip olduğu söylenebilir. Ayrıca, ortalamalar bilgisayarı olan ve olmayan öğrencilerin TPAB ve alt bilgi alanlarına (TB boyutu hariç) ilişkin yeterlilik algılarının “'Iyi düzeyde biliyorum” puan aralığına karşılık geldiğini ve tüm alt boyutlarda bilgisayarı olan öğrencilerin algıladıkları yeterlilik düzeylerinin bilgisayarı olmayanlara göre daha yüksek olduğunu göstermektedir. TB boyutunda ise, bilgisayarı olmayan öğrencilerin "Orta düzeyde biliyorum" kategorisinde yer alırken bilgisayarı olan öğrencilerin "İyi düzeyde biliyorum” kategorisinde yer aldığı belirlenmiştir. 


\section{Öğrencilerin Algıladıkları TPAB Yeterlilik Düzeyleri İle Bilgisayar (Masaüstü/Dizüstü) Kullanma Sıklığı Değişkeni Arasındaki İlişki}

Öğrencilerin algıladıkları teknolojik pedagojik alan bilgisi yeterlilik düzeyleri ile bilgisayar (Masaüstü/dizüstü) kullanma sıklıkları arasında anlamlı bir ilişki olup olmadığına ilişskin bulgular Tablo 8'de verilmiştir.

Tablo 8

Öğrencilerin teknolojik pedagojik alan bilgisi ile bilgisayar kullanma sılkl̆ğ arasındaki ilişki için Pearson korelasyon testi sonuçları $(N=365)$

\begin{tabular}{|c|c|c|}
\hline Boyutlar & & r kullanma sıklığı \\
\hline \multirow{3}{*}{ ТВ } & $r$ & .571 \\
\hline & $p$ & $.000 *$ \\
\hline & $r^{2}$ & .326 \\
\hline \multirow{3}{*}{ PB } & $r$ & .241 \\
\hline & $p$ & $.000 *$ \\
\hline & $r^{2}$ & .058 \\
\hline \multirow{3}{*}{$\mathrm{AB}$} & $r$ & .277 \\
\hline & $p$ & $.000 *$ \\
\hline & $r^{2}$ & .078 \\
\hline \multirow{3}{*}{ ТРВ } & $r$ & .242 \\
\hline & $p$ & $.000 *$ \\
\hline & $r^{2}$ & .059 \\
\hline \multirow{3}{*}{ TAB } & $r$ & .286 \\
\hline & $p$ & $.000 *$ \\
\hline & $r^{2}$ & .082 \\
\hline \multirow{3}{*}{ РАB } & $r$ & .144 \\
\hline & $p$ & $.006 *$ \\
\hline & $r^{2}$ & .021 \\
\hline \multirow{3}{*}{ ТРАВ } & $r$ & .195 \\
\hline & $p$ & $.000 *$ \\
\hline & $r^{2}$ & .038 \\
\hline
\end{tabular}

${ }^{*} \mathrm{p}<0.01$ (Bonferroni düzeltmesi sonrası)

Tablo 8 incelendiğinde öğrencilerin bilgisayar kullanma sıklıkları ile algıladıkları TB yeterlilikleri arasında orta düzeyde $(r=0.571, \quad \mathrm{p}<0.01), \quad \mathrm{PB}$ yeterlilikleri arasında düşük düzeyde $(\mathrm{r}=0.241, \mathrm{p}<0.01)$, AB yeterlilikleri arasında düşük düzeyde $(\mathrm{r}=0.277, \mathrm{p}<0.01)$, TPB yeterlilikleri arasında düşük düzeyde 
$(\mathrm{r}=0.242, \mathrm{p}<0.01)$, TAB yeterlilikleri arasında düşük düzeyde $(\mathrm{r}=0.286, \mathrm{p}<0.01)$, PAB yeterlilikleri arasında düşük düzeyde $(\mathrm{r}=0.144, \mathrm{p}<0.01)$ ve TPAB yeterlilikleri arasında düşük düzeyde $(\mathrm{r}=0.195, \mathrm{p}<0.01)$ pozitif yönde ve anlamlı ilişkiler olduğu görülmüştür. Buna göre eğitim fakültesi son sınıf öğrencilerinin bilgisayar kullanma sıklıkları arttıkça başta TB-Teknolojik bilgi alanı olmak üzere TPAB ve alt alanlarındaki algılanan yeterlilik düzeylerinin de arttığı söylenebilir. $\mathrm{R}^{2}$ değerleri, TB boyutu için orta etki büyüklüğüne işaret ederken diğer alt boyutlar ilişkilerin etki büyüklüklerinin küçük olduğunu göstermektedir.

\section{TPAB Alt Alanlarma Ait Puanların Genel TPAB Yeterlilik Algısını Yordama Düzeyi}

Öğrencilerin TPAB alt alanlarına ait yeterlilik algılarının genel TPAB yeterlilik algısını yordama düzeyine ilişkin çoklu doğrusal regresyon analizi sonuçları Tablo 9'da verilmiştir.

Tablo 9

TPAB alt alanlarına ait puanların genel TPAB yeterlilik algısını yordama düzeyi

\begin{tabular}{lccccccc}
\hline Değişkenler & $B$ & Standart hata & $\beta$ & $t$ & $p$ & Íkili r & Klsmi r \\
\hline Sabit & .640 & .142 & - & 4.510 & $.000^{*}$ & - & - \\
TB & -.007 & .033 & -.010 & -.222 & .824 & .471 & -.012 \\
$\mathrm{~PB}$ & .163 & .048 & .164 & 3.392 & $.001^{*}$ & .615 & .176 \\
$\mathrm{AB}$ & -.082 & .043 & -.088 & -1.887 & .060 & .485 & -.099 \\
$\mathrm{TPB}$ & .242 & .047 & .272 & 5.106 & $.000^{*}$ & .678 & .261 \\
$\mathrm{TAB}$ & .219 & .047 & .246 & 4.663 & $.000^{*}$ & .667 & .239 \\
$\mathrm{PAB}$ & .300 & .052 & .296 & 5.741 & $.000^{*}$ & .688 & .290 \\
\hline $\mathrm{R}=.779$ & $\mathrm{R}^{2}=.606$ & & & & & \\
$\mathrm{~F}_{(6,358)}=91.921$ & $\mathrm{p}=.000^{*}$ & & & & & \\
${ }^{*} \mathrm{p}<0.01$ (Bonferroni düzeltmesi sonrası) &
\end{tabular}

Yapılan çoklu doğrusal regresyon analizi sonucunda TPAB alt bilgi alanlarına ilişkin algılanan yeterlilik puanlarının birlikte, algılanan genel TPAB yeterlilik puanlarıyla yüksek düzeyde anlamlı bir ilişki verdiği bulunmuştur $\left(\mathrm{R}=0.779, \mathrm{R}^{2}=\right.$ 0.606; $\left.F_{(6,358)}=91.921, p=0.000\right)$. Buna göre eğitim fakültesi son sinıf öğrencilerinin algıladıkları TB, PB, AB, TPB, TAB ve PAB yeterlilik düzeyleri, algıladıkları genel TPAB yeterlilik puanlarına ait varyansın yaklaşık \% 61'ini açıklamaktadır. Regresyon katsayılarının anlamlılık düzeyleri dikkate alındığında TB-Teknoloji Bilgisi ve AB-Alan Bilgisi puanlarının genel TPAB puanlarının anlamlı yordayıcısı olmadığı $(p<0.01)$ ve standardize edilmiş regresyon katsayılarından hareketle genel TPAB yeterlilik algısının anlamlı yordayıcılarının önem sırasına göre sadece PAB $(\beta=0.296)$, TPB $(\beta=0.272)$, TAB $(\beta=0.246)$ ve $\mathrm{PB}(\beta=0.164)$ yeterlilik algıları olduğu görülmüştür. 


\section{Sonuç ve Tartışma}

Bu çalışmada iki eğitim fakültesinin farklı bölümlerinde öğrenim gören son sınıf öğrencilerinin teknolojik pedagojik alan bilgilerine (TPAB) ilişkin algıladıkları yeterlilik düzeyleri çeşitli değişkenler açısından incelenmeye çalışılmıştır. Gelen olarak ögrencilerin TPAB ve alt alanlarına ait algıladıkları yeterlilik düzeylerinin ortalama 3.56 - 3.73 (İyi düzeyde biliyorum) arasında değiştiği görülmüştür. Bu bulgu son sınıf öğrencilerin teknolojik bilgi, pedagojik bilgi, alan bilgisi ve bu bilgi alanlarının birleşiminden oluşan bütün bilgi alanlarındaki yeterliliklerini iyi düzeyde algıladıklarını göstermektedir. Bilgi alanları karşılaştırıldığında ise pedagoji bilgisini içeren alt bilgi alanlarından (PAB, TPAB, PB ve TPB) alınan puanların diğerlerine göre nispeten daha yüksek olduğu görülmektedir. Nispeten en düşük ortalamaya sahip bilgi alanının ise 3.56 ortalamayla TB-Teknoloji Bilgisi alanı olduğu söylenebilir. Kaya ve arkadaşları (2011) da benzer şekilde öğretmen adaylarının teknoloji bilgisi konusunda kendilerini nispeten daha az yeterli algıladıklarını bulmuştur. İlgili araştırmalar incelendiğinde araştırmanın genel sonuçlarına paralel olarak öğretmen adaylarının teknopedagojik alan bilgileri konusunda kendilerini yeterli gördükleri ortaya çıkmıştır (Gömleksiz ve Fidan, 2011; Kabakçı Yurdakul, 2011; Kaya ve diğ. 2011; Sancar Tokmak, Yavuz Konokman ve Yanpar Yelken, 2013; Yavuz Konokman ve diğ., 2013). Benzer şekilde Çuhadar ve Yücel (2010) bilgi ve iletişim teknolojilerinin öğretim amaçlı kullanımında yabancı dil öğretmeni adaylarının özyeterlilik algılarını etkileyen etmenleri ortaya koymak amacıyla gerçekleştirdikleri çalışmada katılımcıların büyük çoğunluğunun bilgi ve iletişim teknolojilerinin öğretim amaçlı kullanımı konusunda kendilerini yeterli bulduğunu aktarmıştır. Arslan (2008) öğretmen adaylarının bilgisayar destekli eğitimi gerçekleştirme konusunda yüksek seviyede özyeterlilik algısına sahip olduklarını belirlemiştir. Baki ve arkadaşları (2008), matematik öğretmen adaylarının bilgisayar destekli eğitim konusunda kendilerine güvendiklerini göstermiştir. Yavuz Konokman ve arkadaşları (2013) son sınıf öğretmen adaylarıyla yaptığı çalışmasında öğretmen adaylarının TPAB'ye ilişkin yeterlilik algılarının yüksek olmasını eğitimlerinin son döneminde olmaları ile teknoloji, pedagoji ve alan derslerinin çoğunu almış olmalarıyla açıklamıştır. Son sınıf öğrencileriyle yapılan mevcut çalışmadan elde edilen sonuçlar için de benzer bir yorumda bulunulabilir.

Bu çalışmadan elde edilen sonuçların öğretmen yetiştirme açısından ümit verici olduğu söylenebilir. Çünkü öğretmenlerin derslerinde teknolojiyi kullanabilmeleri için öncelikle kendilerine güvenmeleri gerekmektedir (Akgün, 2013). Teknoloji bilgisi gerekli olmasına rağmen, şayet öğretmenler bu bilgiyi öğrencilerinin daha iyi öğrenmelerini desteklemek için kullanma konusunda kendilerine güvenmiyorlarsa bu bilgi yeterli değildir (Ertmer ve Ottenbreit-Leftwich, 2010). Yan ve Piper (2003) ilköğretim ve ortaöğretim öğretmenleriyle yaptıkları çalışmada teknolojiyi derslerinde kullanan öğretmenler açısından özyeterliliğin bilgi ve beceriden daha önemli olduğunu göstermişlerdir.

Araştırmada bayan ve erkek öğrencilerin algıladıkları TPAB yeterlilik düzeylerinin istatistiksel olarak anlamlı düzeyde farklılaşmadığı tespit edilmiştir. Bu 
sonuç TPAB özyeterlilik algılarının cinsiyet değişkenine göre farklılaşıp farklılaşmadığını ele alan çalışma sonuçlarıyla örtüşmektedir (Gömleksiz ve Fidan, 2011; Kaya ve diğ., 2010; Kaya ve diğ. 2011; Sancar-Tokmak ve diğ. 2013) Ayrıca öğretmen adaylarının bilgisayar destekli eğitime yönelik özyeterlilik algılarının incelendiği çalışmada Baki ve arkadaşları (2008) da cinsiyete göre bir farklılaşmaya rastlamamıştır.

Diğer taraftan katılımcıların algıladıkları TPAB yeterliliklerinin bölüm değişkenine göre anlamlı düzeyde farklılaştığı görülmüştür. Buna göre özellikle BÖTE öğrencilerinin algıladıkları yeterlilik düzeylerini, başta TB-Teknolojik Bilgi alanı olmak üzere $A B$-Alan Bilgisi alanı hariç bütün alanlarda daha yüksek algıladıkları görülmüştür. Benzer şekilde İngilizce öğretmenliği son sınıf öğrencilerinin algıladıkları yeterlilik düzeyinin TPB-Teknolojik Pedagojik Bilgi ve TAB-Teknolojik Alan Bilgisi dışında bütün alanlarda diğer bazı bölümlerden daha yüksek çıkmıştır. Diğer taraftan İlköğretim Matematik ve Sosyal Bilgiler öğretmenliği son sınıf öğrencilerinin birçok TPAB alanı itibariyle kendilerini daha az yeterli algıladıkları anlaşılmıştır. Özellikle BÖTE son sınıf öğrencilerinin başta teknolojiyle ilgili bilgi alanlarında kendilerini diğer bölümlere göre daha yeterli algılamaları beklenen bir bulgu olarak değerlendirilebilir. Kaya ve arkadaşları (2011) da başta teknik eğitim fakültesi öğrencileri olmak üzere bilişim teknolojileri öğretmen adaylarının teknolojik pedagojik alan bilgisi özyeterlilik algılarını yüksek bulmuştur. Gömleksiz ve Fidan (2011) ise Eğitim Fakültesinde Pedagojik Formasyon Programına kayıtlı öğretmen adaylarının web pedagojik içerik bilgisi öz-yeterliliklerine ilişkin algı düzeylerini belirlemeyi amaçladığı genel web alt boyutu açısından Coğrafya bölümü mezunlarının diğer tüm bölüm mezunlarına göre kendilerini daha yeterli buldukları, en düşük yeterlilik düzeyine sahip öğretmen adaylarının ise Biyoloji bölümü mezunları olduğunu bulmuştur.

Bilgisayar (masaüstü/dizüstü) sahibi olan öğrencilerin tüm alanlardaki yeterlilik algısı ortalamalarının bilgisayar sahibi olmayanların ortalamalarına göre daha yüksek olduğu saptanmıştır. Alt boyutlar incelendiğinde öğrencilerin TPAB yeterlilik algılarının AB, PB ve TB boyutlarında bilgisayarı olanların lehine anlamlı bir şekilde arttığı belirlenmiştir. Benzer şekilde Yavuz Konokman ve arkadaşları (2013) teknolojiye erişim düzeyi yüksek olan öğretmen adaylarının TPAB düzeylerini daha yüksek algıladıklarını saptamıştır. Kara (2011) da kendisine ait bilgisayarı olan öğretmenlerin bilgi ve iletişim teknolojilerini kullanma yeterliliklerinin bilgisayarı olmayan öğretmenlere göre daha yüksek olduğunu saptanmıştır. Tezci (2011) de bilgisayar sahibi olmayan sınıf öğretmenlerinin teknoloji entegrasyonuna ilişkin okul kültürü algılarının daha olumsuz olduğunu bulmuştur. Diğer taraftan Baki ve arkadaşları (2008) ise bilgisayara sahip olup olmama durumu açısından matematik öğretmen adaylarının bilgisayar destekli eğitim özyeterlilik algıları arasında anlamlı bir farka rastlanmamışlardır.

Araştırmada TPAB yeterlilik düzeyleri ile bilgisayar kullanma sıklıkları karşılaştırılmış ve öğrencilerin bilgisayar kullanma sıklıkları arttıkça başta TBTeknolojik bilgi alanı olmak üzere TPAB ve alt alanlarındaki yeterlilik düzeylerinin de 
$\operatorname{arttığı~sonucuna~ulaşılmıştır.~Benzer~şekilde~Yavuz~Konokman~arkadaşları~(2013)~}$ teknolojiye erişim, yeni teknolojilere ilgi ve teknolojiyi kullanma düzeyleri yüksek olan öğretmen adaylarının TPAB düzeylerini daha yüksek algıladıkları sonucuna ulaşmıştır. Baki ve arkadaşları (2008) da bilgisayar kullanım sıklığının yüksek olmasının öğretmen adaylarının bilgisayar destekli eğitim özyeterlilik alg1 düzeylerini olumlu yönde etkilediğini belirtmişlerdir. Ayrıca Yurdakul Kabakçı (2011) da Türkiye genelinde yaptığ1 çalışmada öğretmen adaylarının bilgi ve iletişim teknolojilerini kullanma düzeylerinin arttıkça, teknopedagojik eğitim yeterliliklerinin de arttı̆̆1 sonucuna ulaşmıştır.

TPAB alt alanlarına ait yeterlilik algılarının genel TPAB yeterlilik algısını ne düzeyde yordadığına ilişkin çoklu doğrusal regresyon analizi sonuçları öğrencilerin genel TPAB yeterlilik algılarının en güçlü yordayıcılarının sırasıyla PAB-Pedagojik Alan Bilgisi $(\beta=.296)$, TPB-Teknolojik Pedagoji Bilgisi $(\beta=.272)$, TAB-Teknolojik Alan Bilgisi $(\beta=.246)$ ve PB-Pedagoji Bilgisi $(\beta=.164)$ yeterlilik algıları olduğunu göstermiştir. Diğer yandan TB-Teknoloji Bilgisi ve AB-Alan Bilgisi yeterlilik algılarının anlamlı yordayıcılar olmadığı görülmüştür. Chai ve arkadaşları (2010) ise yaptıkları çalışmada genel TPAB algısının en güçlü yordayıcısının pedagojik bilgi olduğunu bulmuştur. Buradan hareketle tek başına teknoloji ya da alan bilgisine ilişkin yeterlilik algısının genel TPAB algısına anlamlı bir katkı yapmadığı; en önemli katkının alanın nasıl öğretilmesi gerektiğine ilişkin pedagojik alan bilgisi, teknolojinin pedagojik bir şekilde nasıl kullanılması gerektiğine ilişkin teknolojik pedagoji bilgisi, teknolojinin alan içindeki yerine ilişkin teknolojik alan bilgisi ve genel pedagoji bilgisine ait yeterlilik algısından kaynaklandığg söylenebilir.

\section{Öneriler}

Araştırmadan elde edilen bulgular doğrultusunda uygulamacılara ve araştırmacılara bazı öneriler sunulabilir. Öncelikle araştırma bulguları genel olarak öğretmen adaylarının teknoloji bilgisi konusunda kendilerini nispeten daha az yeterli algıladıklarını ortaya koymuştur. Diğer taraftan bilgisayar sahibi olmanın öğretmen adaylarının teknoloji bilgisine ilişsin yeterlilik algısı üzerinde genişe yakın bir etki büyüklüğüyle manidar bir fark yarattığı görülmüştür. Son olarak da bilgisayar kullanma sıklığının teknoloji bilgisine ilişkin yeterlilik algısıyla pozitif yönde orta düzeyde anlamlı bir ilişki verdiği anlaşılmıştır. Tüm bu bulgular öğretmen adaylarının teknoloji bilgisini arttırmaya yönelik önlemler alınması gereğine işaret etmektedir. Bu amaçla başta temel bilgisayar dersleri olmak üzere öğretim teknolojileriyle ilgili derslerin programları gözden geçirilerek, öğrencilere teknolojiyi okuryazarlığı kazandırabilme konusundaki yeterlilikleri sorgulanmalıdır. Ayrıca öğretmen adaylarına sunulan bilişim teknolojilerine ilişkin derslerin sadece birinci sınıfla sınırlı tutulmayıp yıllara yayılması ve proje, burs vb. kapsamında her öğrenciye bilgisayar tedarik edilmesi önerilebilir.

Öğretmen adaylarının TPAB ve alt bilgi alanlarının bölümler açısından değerlendirilmesi sonucunda İlköğretim Matematik ve Sosyal bilgiler öğretmenliği bölümleri öğretmen adaylarının TPAB ve alt bilgi dallarına ait yeterlilik düzeylerinin 
diğer bölümlerden daha düşük olduğu görülmüştür. Bu durumun sebepleri, ilgili bölümlerce araştırılmalı ve çözümler üretilmelidir. 


\section{Kaynakça}

Abbitt, J. \& Klett, M. (2007). Identifying influences on attitudes and self-efficacy beliefs towards technology integration among pre-service educators. Electronic Journal for the Integration of Technology in Education, 6, 28-42.

Abbitt, J. T. (2011). An investigation of the relationship between self-efficacy beliefs about technology integration and technological pedagogical content knowledge (TPACK) among preservice teachers. Journal of Digital Learning in Teacher Education, 27(4), 134-143.

Abdi, H. (2010). Holm's sequential bonferroni procedure. In N. Salkind (Ed.), Encyclopedia of research design (pp. 1-8). Thousand Oaks, CA: Sage.

Akgün, F. (2013). Öğretmen adaylarının web pedagojik içerik bilgileri ve öğretmen özyeterlilik algıları ile ilişkisi. Trakya Üniversitesi Eğitim Fakültesi Dergisi, 3(1), 48-58.

Akkuş, Z. (2013). Sosyal bilgiler öğretmen adaylarının öz yeterlilik inanç düzeylerinin belirlenmesi üzerine bir çalışma. Dicle Üniversitesi Ziya Gökalp Eğitim Fakültesi Dergisi, 20, 102-116.

Al awaidi, H. M. \& Alghazo, I.M. (2012). The effect of student teaching experience onpreservice elementary teachers' self-efficacy beliefs for technology integration in the UAE. Education Tech Research Dev, 60, 923-941.

Alayyar, G., Fisser, P., \& Voogt, J. (2012). Developing technological pedagogical content knowledge in pre-service science teachers: support from blended learning. Australasian Journal of Educational Technology, 28(8), 1298-1316.

Albion, P.R. (1999, ). Self-efficacy beliefs as an indicator of teachers' preparedness forteaching with technology. In Proceedings of 10th International Conference of the Society for Information Technology \& Teacher Education (pp.1602-1608). San Antonio, United States.

Albion, P. R. (2000). Interactive multimedia problem-based learning for enhancing preservice teachers' selfefficacy beliefs about teaching with computers: Design, development and evaluation (Unpublished doctoral thesis). University of Southern Queensland, Toowoomba.

Aldunate, R., \& Nussbaum, M. (2013). Teacher adoption of technology. Computers in Human Behavior, 29(3), 519-524.

Angeli, C. C., \& Valanides, N. N. (2009). Epistemological and methodological issues for the conceptualization, development, and assessment of ict-tpck: Advances in technological pedagogical content knowledge (TPCK). Computers \& Education, 52(1), 154-168.

Archambault, L., \& Crippen, K. (2009). Examining TPACK among K-12 online distance educators in the United States. Contemporary Issues in Technology and Teacher Education, 9(1), 71-88. 
Archambault, L. M. \& Barnett, J. H. (2010). Revisiting technological pedagogical content knowledge: Exploring the TPACK framework. Computers \& Education, 55, 1656-1662.

Armstrong, V., Barnes, S., Sutherland, R., Curran, S., Mills, S., \& Thompson, I. (2005). Collaborative research methodology for investigating teaching and learning: the use of interactive whiteboard technology. Educational Review, 57(4), 457-469.

Arslan, A. (2008). Öğretmen adaylarının bilgisayar destekli eğitim yapmaya yönelik tutumları ile öz-yeterlilik algıları arasındaki İlişki. Elektronik Sosyal Bilimler Dergisi, 7(24), 101-109.

Baki, A., Kutluca, T. \& Birgin, O. (2008). Matematik ögretmeni adaylarının bilgisayar destekli eğitime yönelik öz-yeterlilik algllarının incelenmesi. VIII. International Educational Technology Conference, Anadolu University, Eskişehir, Turkey.

Bandura, A. (1997). Exercise of personal and collective efficacy in changing societies. In A. Bandura (Ed.), Self-efficacy in changing societies (pp. 1-45). New York: Cambridge University Press.

Bıkmaz, F.H. (2004). Sınıf öğretmenlerinin fen öğretiminde öz yeterlilik inancı ölçeğinin geçerlik ve güvenirlik çalışması. Milli Eğitim Dergisi, 161. http://dhgm.meb.gov.tr/yayimlar/dergiler/Milli_Egitim_Dergisi/161/bikmaz.htm adresinden alınmıştır.

Bozkurt, A., \& Cilavdaroğlu, A. (2011). Matematik ve sınıf öğretmenlerinin teknolojiyi kullanma ve derslerine teknolojiyi entegre etme algıları. Kastamonu Üniversitesi Kastamonu Eğitim Fakültesi, 19(3), 859-870.

Büyüköztürk, Ş., Çakmak Kılıç, E., Akgün , Ö.E., Karadeniz, Ş. ve Demirel, F. (2010). Bilimsel araştırma yöntemleri (5. Baskı). Ankara: Pegem Akademi.

Chai, C. S., Koh, J. H. L., \& Tsai, C.C. (2010). Facilitating preservice teachers' development of technological, pedagogical, and content knowledge (tpack). Educational Technology \& Society, 13(4), 63-73.

Cohen, J. (1988). Statistical power analysis for the behavioral sciences ( $2^{\text {nd }}$ ed.). Hillsdale, NJ: Erlbaum.

Çakır, R. \& Yıldırım, S. (2009). What do computer teachers think about the factors affecting technology integration in schools? Illköğretim Online, 8(3), 952-964.

Çuhadar, C. \& Yücel, M. (2010). Yabancı dil öğretmeni adaylarının bilgi ve iletişim teknolojilerinin öğretim amaçlı kullanımına yönelik özyeterlilik algıları. Pamukkale Üniversitesi Eğitim Fakültesi Dergisi, 27, 199-210.

Demir, S., \& Bozkurt, A. (2011). İlköğretim matematik öğretmenlerinin teknoloji entegrasyonundaki öğretmen yeterliliklerine ilişkin görüşleri. Illköğretim Online, 10(3), 851-860.

Demir, S., Özmantar, M.F., Bingölbali, E. \& Bozkurt, A. (2011). Sınıf öğretmenlerinin teknoloji kullanımlarının irdelenmesi. 5th International Computer \& Instructional Technologies Symposium, Furat University, Elazı ğ, Turkey. 
Demiralay, R. ve Karadeniz, Ş. (2010). The effect of use of information and communication technologies on elementary student teachers' perceived information literacy self-efficacy. Kuram ve Uygulamada Ĕgitim Bilimleri (KUYEB), 10(2), 841-851.

Demiraslan, Y. ve Koçak Usluel, Y. K. (2008). Ict integration processes in Turkish schools: using activity theory to study issues and contradictions. Australasian Journal of Educational Technology, 24(4), 458-474.

Enochs, L. G., Riggs, I. M., \& Ellis, J. D. (1993). The development and partial validation of microcomputer utilization in teaching efficacy beliefs instrument in a science setting. School Science and Mathematics, 93(5), 257-263.

Erdem, M. (2007). Self-efficacy levels of teachers in information and computer literacy. World Applied Sciences Journal (WASJ), 2(4), 399-405.

Erdoğan, A., \& Sahin, I. (2010). Relationship between math teacher candidates' technological pedagogical and content knowledge (TPACK) and achievement levels. Procedia Social and Behavioral Sciences, 2(2), 2707-2711.

Ertmer, P. A., Conklin, D. ve Lewandowski, J. (2003). Increasing preservice teachers’ capacity for technology integration through the use of electronic models. Teacher Education Quarterly, 30(1), 95-112.

Ertmer, P. A. ve Ottenbreit-Leftwich, A. T. (2010). Teacher technology change: How knowledge, confidence, beliefs, and culture intersect. Journal of Research on Technology in Education, 42(3), 255-284.

Gömleksiz, M. N. \& Fidan, E. K. (2011). Pedagojik formasyon programı öğrencilerinin web pedagojik içerik bilgisine ilişkin öz-yeterlilik algı düzeyleri. Turkish Studies International Periodical for the Languages, Literature and History of Turkish or Turkic, 6(4), 593-620.

Graham, C., Burgoyne, N., Cantrell, P., Smith, L., Clair St., L., \& Harris, R. (2009). tpack development in science teaching: measuring the tpack confidence of inservice science teachers. Techtrends, 53(5), 70-79.

Gürbüztürk, O., Duruhan, K. ve Şad, S.N. (2009). The association between preservice teachers' previous formal education experiences and their visions about their future teaching. Illkögretim-Online [Elementary Education Online], 8(3), 923-934.

Harris, J., Mishra, P. and Koehler, M. (2009). Teachers' technological pedagogical content knowledge and learning activity types: Curriculum-based technology integration reframed. Journal of Research on Technology in Education, 41(4), 393416.

İşman, A. (2002). Sakarya ili öğretmenlerinin eğitim teknolojileri yönündeki yeterlilikleri. The Turkish Online Journal of Educational Technology - TOJET, 1(1), 72-91.

Jang, S., \& Tsai, M. (2012). Exploring the tpack of Taiwanese elementary mathematics and science teachers with respect to use of interactive whiteboards. Computers \& Education, 59(2), 327-338. 
Kara, S. (2011). İlköğretim okullarında görev yapan öğretmenlerin bilgi ve iletişim teknolojileri yeterliliklerinin belirlenmesi (İstanbul Örneği) (Yayınlanmamış Yüksek Lisans Tezi). Bahçeşehir Üniversitesi, İstanbul.

Karasar, N. (2012). Bilimsel araştırma yöntemi. Ankara: Nobel Yayın Dağıtım.

Kaya Z., Emre, İ. ve Kaya, O. N. (2010). Sınıf ögretmeni adaylarının teknolojik pedagojik alan bilgisi (TPAB) açısından öz-güven seviyelerinin belirlenmesi. 9. Ulusal Sınıf Öğretmenliği Eğitimi Sempozyumunda sunulmuş sözlü bildiri, Fırat Üniversitesi, Elazı ̆̆g, Türkiye.

Kaya, Z., Özdemir,T. Y., Emre,G., Kaya, O. N.(2011). Bilişim teknolojileri öğretmen adaylarının teknolojik pedagojik alan bilgisi öz yeterlilik seviyelerinin belirlenmesi. Paper presented at the International Computer \& Instructional Technologies Symposium, Firat University, Elazığ, Turkey.

Kazu İ. Y. ve Erten P. (2011). Sınıf öğretmeni adaylarının web pedagojik içerik bilgisine ilişkin görüşleri. $\quad 10$. Ulusal Sınıf Ö̆ğretmenliği Eğitimi Sempozyumunda sunulan sözlü bildiri, Sivas, Türkiye.

Kreijns, K., Vermeulen, M., Kirschner, P., Van Buuren, H., \& Van Acker, F. (2013). Adopting the Integrative Model of Behaviour Prediction to explain teachers' willingness to use ICT: A perspective for research on teachers' ICT usage in pedagogical practices. Technology, Pedagogy and Education, 22(1), 55-71

Koehler, M.J., \& Mishra, P. (2005a). Teachers learning technology by design. Journal of Computing in Teacher Education, 21(3). 94-102.

Koehler, M. J., \& Mishra, P. (2005b). What happens when teachers design educational technology? The development of Technological Pedagogical Content Knowledge. Journal of Educational Computing Research, 32(2), 131-152.

Koehler, M.J., \& Mishra, P. (2008). Introducing tpck. In AACTE Committee on Innovation and Technology (Ed.), The handbook of technological pedagogical content knowledge (TPCK) for educators (pp. 3-29). Mahwah, NJ: Lawrence Erlbaum Associates.

Koh, J.H.L and Sing, C.C. (2011) Modeling pre-service teachers' technological pedagogical content knowledge (tpack) perceptions: the influence of demographic factors and TPACK constructs. Paper presented at ASCILITE Australian Society for Computers in Learning in Tertiary Education Annual Conference, Australia.

Kurbanoğlu, S. (2004). Öz-yeterlilik inancı ve bilgi profesyonelleri için önemi. Bilgi Dünyası, 5(2), 137-152.

Kutluca, T. \& Ekici, G. (2010). Öğretmen adaylarının bilgisayar destekli eğitime ilişkin tutum ve öz-yeterlilik algılarının incelenmesi. Hacettepe Üniversitesi Ĕgitim Fakültesi Dergisi, 38, 177-188.

Kuş, B. B. (2005). Öğretmenlerin bilgisayar öz-yeterlilik inançları ve bilgisayar destekli ögretime yönelik tutumları (Yayınlanmamış yüksek lisans tezi). Hacettepe Üniversitesi, Ankara. 
Liu, H.-S. (2011). Factors related to pedagogical beliefs of teachers and technology integration. Computers \& Education, 56(4), 1012-1022.

Martinovic, D, \& Zhang, Z. (2012). Situating ict in the teacher education program: Overcoming challenges, fulfilling expectations. Teaching and Teacher Education, 28, 461-469.

Mishra, P. \& Koehler, M.J. (2006). Technological pedagogical content knowledge: a framework for integrating technology in teacher knowledge. Teachers College Record, 108(6), 1017- 1054.

Mishra, P. \& Koehler, M.J. (2008). Introducing technological pedagogical content knowledge. Paper presented in Annual meeting of the American Educational Research Association, March 24-28, New York, US.

Muijs, D. (2004). Doing quantitative research in education with spss. London: Sage.

Mutluoğlu, A. \& Erdoğan, A. (2012). Ilköğretim matematik öğretmenlerinin tpab düzeylerinin farklı değişkenler açısından incelenmesi. Paper presented at the $6^{\text {th }}$ International Computer and Instructional Technologies Symposium, 4th - 6th October, Gaziantep University, Gaziantep, Turkey.

Peralta, H. \& Costa, F.A. (2007). Teacher's competence and confidence regarding the use of ICT. Educational Sciences Journal, 3, 75-83.

Sancar Tokmak, H., Yavuz Konokman, G. ve Yanpar Yelken, T. (2013). Mersin üniversitesi okul öncesi öğretmen adaylarının teknolojik pedagojik alan bilgisi (tpab) özgüven algılarının incelenmesi. Ahi Evran Üniversitesi Kırşehir Ĕgitim Fakültesi Dergisi (KEFAD), 14(1), 35-51.

Schmidt, D. A., Baran, E., Thompson, A. D., Koehler, M. J., Mishra, P., \& Shin, T. (2009). Technological pedagogical content knowledge (tpack): the development and validation of an assessment instrument for preservice teachers. Journal of Research on Technology in Education, 42(2), 123-149.

Shulman, L. S. (1986). Those who understand: knowledge growth in teaching. Educational Researcher, 15(2), 4-14.

Sutton, S. R. (2011). The preservice technology training experiences of novice teachers. Journal Of Digital Learning In Teacher Education, 28(1), 39-47.

Şad, S.N. (2008). Using mobile phone technology in efl classes. English Teaching Forum. 46(4), 34-39

Şad, S.N. \& Özhan, U. (2012). Honeymoon with iwbs: a qualitative insight in primary students' views on instruction with interactive whiteboard. Computers \& Education, 59(4), 1184-1191.

Şad, S.N. \& Göktaş, Ö. (2014). Preservice teachers’ perceptions about using mobile phones and laptops in education as mobile learning tools. British Journal of Educational Technology-BJET, 45(4), 606-618

Şahin, İ. (2011). Development of survey of technological pedagogical and content knowledge (tpack). TOJET-The Turkish Online Journal of Educational Technology, 
10(1), 97-105.

Tezci, E., (2011). Turkish primary school teachers' perceptions of school culture regarding ict integration. Education Tech Research Dev, 59, 429-443.

Timur, B. \& Taşar, M.F. (2011a). Teknolojik pedagojik alan bilgisi öz güven ölçeğinin (tpabögö) Türkçe’ye uyarlanması. Gaziantep Üniversitesi Sosyal Bilimler Dergisi, 10(2), 839 -856.

Timur, B., \& Taşar, M.F. (2011b). In-service science teachers' technological pedagogical content knowledge confidences and views about technology-rich environments. CEPS Journal, 1(4), 11-25.

Tsai, C.C. (2008) The preferences toward constructivist Internet-based learning environments among university students in Taiwan. Computers in Human Behavior, 24, 16-21.

Tschannen-Moran, M., \& Hoy, A. W. (2001). Teacher efficacy: Capturing an elusive construct. Teaching and Teacher Education, 17(7), 783-805.

Wang, L., Ertmer, P. A., \& Newby, T. J. (2004). Increasing preservice teachers' self efficacy beliefs for technology integration. Journal of Research on Technology in Education, 36(3), 231-250.

Yan, W. \& Piper, D. (2003). The relationship between leadership, self-efficacy, computer experience, attitudes, and teachers' implementation of computers in the classroom. In Proceedings of Society for Information Technology \& Teacher Education International Conference 2003 (pp.1057-1060). Chesapeake, VA: AACE.

Yavuz Konokman, G, Yanpar Yelken, T. ve Sancar Tokmak, H. (2013). Sınıf öğretmeni adaylarının tpab’lerine ilişkin algılarının çeşitli değişkenlere göre incelenmesi: Mersin üniversitesi örneği. Kastamonu Ĕ̆itim Dergisi, 21(2), 665-684.

Yenilmez, K. ve Kakmacı, Ö. (2008). İlköğretim matematik öğretmenliği bölümü öğrencilerinin öz yeterlilik inanç düzeyleri. Eskişehir Osmangazi Üniversitesi Sosyal Bilimler Dergisi, 9(2), 1-22.

Yılmaz, M. (2007). Sınıf öğretmeni yetiştirmede teknoloji eğitimi. Gazi University Journal of Gazi Educational Faculty (GUJGEF), 1, 155-167.

Yılmaz, M., Köseoğlu, P., Gerçek, C. ve Soran, H. (2004). Öğretmen öz-yeterlilik inanc1. Bilim ve Aklın Aydınlı̆̆ında Ĕ̈itim, 5(58), 50-54.

Yurdakul Kabakçı, I. (2011). Öğretmen adaylarının teknopedagojik eğitim yeterliliklerinin bilgi ve iletişim teknolojilerini kullanımları açısından incelenmesi. Hacettepe Üniversitesi Eğitim Fakültesi Dergisi (H. U. Journal of Education), 40, 397-408. 